\title{
()
}

European Bank

for Reconstruction and Development

\section{Does transition make you happy?}

\author{
Peter Sanfey and Utku Teksoz
}

\begin{abstract}
This paper analyses life satisfaction in transition countries using evidence from the World Values Survey. The paper demonstrates that individuals in transition economies on average record lower values of self-reported satisfaction with life compared with those in non-transition countries. An econometric analysis shows that females, people with higher levels of education and higher incomes are happier, and happiness declines with age until the early-fifties. Self-employed people in transition countries show a higher level of satisfaction relative to full-time employees, in contrast to evidence from non-transition countries. A comparison across time for a smaller sample of countries shows that life satisfaction levels have returned close to pre-transition levels in most cases, after a dip in the mid1990s. In addition, satisfaction levels are highest in those countries where market-oriented reforms are most advanced and where inequality is lower.
\end{abstract}

Keywords: Happiness; transition; reforms

JEL Classification Number: D10, 053, P20

Address for Correspondence: European Bank for Reconstruction and Development, One Exchange Square, London EC2A 2JN, UK.

Phone: +44 207338 6227; Fax: +44 207338 6111;

E-mail: sanfeyp@ebrd.com; teksozu@ebrd.com.

Peter Sanfey is a Lead Economist at the EBRD, and Utku Teksoz is an economic analyst at the EBRD and a Ph.D. candidate at the University of Munich.

We are grateful to Willem Buiter, Andrew Clark, Tomas Danestad, Pierre Garrouste, Yannis Georgellis, Stephan Klasen, Orsolya Lelkes, Ceema Namazie and Bruce Rayton for helpful comments on an earlier draft.

The working paper series has been produced to stimulate debate on the economic transformation of central and eastern Europe and the CIS. Views presented are those of the authors and not necessarily of the EBRD. 


\section{INTRODUCTION}

Life is often difficult for people living in transition countries. More than fifteen years after the fall of the Berlin wall in late-1989, many individuals in central and eastern Europe and the Commonwealth of Independent States (CIS) are still struggling to adapt to the changes that have taken place over that period. In most transition countries, the worst is now over: the "transition recessions" of the early- and mid-1990s are past and the region as a whole ${ }^{1}$ has been growing strongly for several years, out-performing the world economy (see EBRD, 2004). Reforms are also proceeding steadily in most countries, bringing substantial benefits in the form of higher, long-term economic growth. ${ }^{2}$ But the problems brought by transition are far from being resolved. In many countries, these include high unemployment, widespread poverty and a severe drop in living standards for some of the more vulnerable sections of society.

This paper takes a fresh, and somewhat unorthodox, approach to examine the effects of transition on different segments of society. Rather than analyse "hard" data on income, unemployment, wages and the like, we instead use a subjective, self-determined assessment of life satisfaction as the measure of an individual's welfare or utility. This is then correlated with socio-economic characteristics such as gender, age, income group and labour market status, as well as with macroeconomic variables and indicators of progress in transition. The individual-level data are drawn from the World Values Survey (WVS), a large, multi-country survey that covers a wide range of countries around the world. This data set allows a comparison between transition and non-transition countries, highlighting the extent to which the former are different from the latter.

Research on the "economics of happiness" is becoming increasingly common among economists. The limitations of self-reported data on well-being and the problems with comparing answers across individuals, and across countries, are well known. But economists increasingly recognise that valuable information can be gleaned from individuals' responses to questions about their general welfare. To date, however, few papers have adopted this approach in a transition context. This type of analysis may be particularly fruitful for transition countries, where accurate objective data are often hard to find because of weaknesses in national statistical agencies and the failure to account for the large informal economy. Subjective data can, therefore, give an alternative, complementary perspective on welfare measurement in the region and the effects - both positive and negative - of transition.

This paper attempts to answer several questions. The first question is, do the socio-economic patterns in life satisfaction observed in non-transition countries also hold in the transition region? The answer is that they do to some extent, but with important differences. In this regard, two results from the transition sample stand out. The first is that the self-employed are happier than those in full-time employment. This is consistent with the evidence of Dutz et al. (2004) that entrepreneurship is a high-reward strategy for the minority in transition countries who have adopted this approach. The second result of interest is that, while satisfaction shows a U-shape pattern when graphed against age (in common with other studies), the decline continues into the fifties, whereas the minimum point is usually reached much earlier in nontransition countries.

The second question is whether satisfaction is correlated with external macroeconomic variables such as growth and inflation. In the transition context, relevant questions are whether the state of reforms and the degree of inequality are important. Our results show a positive relation between reforms, as measured by the well-known EBRD transition indicators, and satisfaction. However, the size and statistical significance of this result is dependent on

\footnotetext{
${ }^{1}$ The region comprises of the new European Union members of central eastern Europe and the Baltic states (CEB), south-eastern Europe (SEE) and the CIS.

${ }^{2}$ For a review of the recent literature on the relationship between reforms and growth in transition, and a presentation of some new evidence, see Falcetti et al. (2005).
} 
the specification used and the inclusion of other macroeconomic variables such as GDP per capita. Interestingly, a high degree of inequality in transition countries is associated with lower life satisfaction.

Finally, the paper contrasts the results from the most recent wave of the WVS with two previous waves, based on a smaller sample of transition countries. A V-shaped pattern through time is apparent in the majority of countries: that is, average life satisfaction tended to fall during the early years of transition, but returned close to the pre-transition level after about a ten-year period, and even above this level in a couple of cases.

The paper is structured as follows. Section 1 contains a brief overview of some of the key recent literature on the economics of happiness. Section 2 describes the WVS and presents some summary tables from the latest wave. Section 3 presents the econometric results, based on ordered probit analysis, on the correlates of life satisfaction. Section 4 contains an extended analysis based on three different waves of the survey, and section 5 concludes the paper. 


\section{HAPPINESS AND TRANSITION: WHAT DO WE KNOW?}

An exciting development in social sciences in recent years is the growing interaction between economics and psychology. One of the most visible signs of this phenomenon is the dramatic increase in interest, especially among economists, in the analysis of subjective measures of well-being. ${ }^{3}$ This literature, commonly known as the "economics of happiness", has already led to several authoritative surveys in economics journals, as well as a book by two of the leading authors in the area, Frey and Stutzer (2002a). ${ }^{4}$ The literature has gone a long way to establish that surveys of individuals' feelings about their well-being can elicit useful information, that such responses contain predictive power for future behaviour, and that they can be compared in a meaningful way across individuals, countries and time.

Several robust patterns have emerged from a wide number of empirical studies around the world. For example, it is generally found that happiness is positively correlated with education and income, and negatively with unemployment and ill-health. Such results are not surprising. More unexpected, perhaps, is the fact that overall well-being in industrialised economies does not appear to have increased much or at all over the past decades, despite the enormous increase in real incomes and living standards (see Blanchflower and Oswald, 2004; Layard, 2005). This apparent puzzle is generally explained by adaptation theories, namely, that people become used to new circumstances and adjust their notions of well-being accordingly, and by the fact that people are often more concerned with their relative status (compared to those around them) rather than with some absolute measure of income or consumption. These are highly relevant considerations when analysing transition economies, where the upheavals have been huge and adaptation is likely to take some time, and where people may have inherited a strong aversion to inequality.

We make no attempt here to survey the broad literature; instead we concentrate on those papers devoted wholly or in part to analysing happiness in transition economies. This literature is rather sparse. Frey and Stutzer (2002b) note that "there is still a lack of data on subjective well-being in developing and transition countries" (p. 431). Graham (2004) makes the same point, noting that when such studies exist, they tend to be for individual countries only. This is an important gap that needs to be filled, as there are at least two reasons why this type of analysis is particularly relevant for the region.

First, the transition process has involved a major upheaval for most people, and therefore one would expect to see this reflected in happiness scores, particularly in the early years of transition. Similarly, measures of happiness would be expected to increase over time as circumstances have improved and people have become used to the new regime. These hypotheses can be tested if one has access to subjective data on transition countries at different stages of transition.

Second, objective, reliable data in transition economies are often hard to find. In most countries of the region, there is a large informal economy and statistical coverage of the newly emerging private sector is sometimes patchy. Subjective measures of well-being can, therefore, provide a useful complement to conventional economic data, and can help identify those groups or regions most affected by transition.

\footnotetext{
${ }^{3}$ The issue has also attracted considerable media interest recently. See, for example, the special edition of Time magazine entitled "The Science of Happiness", January 17, 2005, and an article by Larry Elliott entitled "Happiness may be in the mind but the state still has a role to play" in The Guardian, February 28, 2005.

${ }^{4}$ Other recent surveys include Oswald (1997), Frey and Stutzer (2002b), and Layard (2005). There is extensive literature on the subject in psychology journals; Diener and Seligman (2004) is a useful overview. Other inter-disciplinary initiatives worth noting in this area include an internet site on happiness research, organised and managed by the sociologist Ruut Veenhoven (http://www2.eur.nl/fsw/research/happiness/), and a journal called the Journal of Happiness Studies.
} 
One fact emerges clearly from cross-country surveys of subjective well-being: transition economies consistently appear at or near the bottom of the list. In Veenhoven's world database of happiness, there is a summary table on average happiness in 68 nations during the 1990s, where happiness is defined as how much people enjoy their life as a whole. The bottom five countries are (in descending order) Russia, Georgia, Armenia, Ukraine and Moldova, all in the former Soviet Union (FSU). Other transition countries such as Belarus, Bulgaria and the Kyrgyz Republic also score poorly. A similar pattern is apparent in Table 2.2 of Frey and Stutzer (2002a), with former Soviet Union countries doing badly on happiness scores and central European transition countries scoring higher but still below not only the richest OECD countries but also most of those in Asia or central and south America. ${ }^{5}$

Halliwell (2002) uses the first three waves of the World Values Survey to estimate a general happiness equation for all countries (similar to the approach we adopt below). He aggregates the transition countries into two groups - eastern Europe and the former Soviet Union. Interestingly, one experiment shows that subjective well-being was very low in both 1990 and the mid-1990s in the FSU, while in eastern Europe it started off even lower than in the FSU, but rose significantly in the intervening period.

Very few papers focus solely on a range of transition countries. ${ }^{6}$ Hayo and Seifert (2002) analyse a subjective measure of economic well-being in ten eastern European countries in the early 1990s. This measure has a reasonably strong correlation with life satisfaction in the first wave of the survey in 1991 (the only year when both questions were asked). It is also correlated with GDP per capita, with the correlation rising over time, suggesting that objective data have become more accurate over time.

A number of other papers analyse the correlates of happiness in a specific country. Namazie and Sanfey (2001) focus on one of the poorest transition countries - the Kyrgyz Republic using a household survey carried out in 1993. While some of the results are similar to those in empirical studies of more advanced countries, several are different. In particular, satisfaction appears to decline steadily with age, at least until the early sixties, in contrast to the U-shape pattern (with a mid-point somewhere around 40) commonly found in more advanced countries. ${ }^{7}$ Also, there is no correlation between happiness and education in transition countries, possibly (the authors speculate) because skills and education acquired under the old regime are of little use in the new circumstances.

Several papers examine happiness in Russia. For example, Veenhoven (2001) and Graham et al. (2004), both find high levels of unhappiness on average among Russians. Similar to Namazie and Sanfey (2001), Graham et al. also fail to find a significant impact of education on happiness in most specifications, while a U-shape does emerge with respect to age, but with a minimum around 47 years. Interestingly, however, the panel nature of the data allows the authors to identify tentatively a two-way causal effect between income and happiness. Senik (2002) identifies an important positive contribution to happiness by the relevant "reference" income. Another interesting finding is that the self-employed in Russia tend to be happier than employees, in contrast to evidence from Latin America (see Graham, 2004). However, this finding is not replicated in Lelkes's (2002) findings for Hungary. ${ }^{8}$

\footnotetext{
${ }^{5}$ One possible explanation for the low scores in some countries is the fact that many young, educated people with entrepreneurial skills have emigrated during the transition, and it is those people who, on average, tend to report higher satisfaction scores.

${ }^{6}$ Gruen and Klasen (2005) is a work in progress that looks at developments in a range of indicators, including subjective ones, during the transition to assess overall changes in welfare throughout the period.

${ }^{7}$ See, for example, Clark et al. (1996).

${ }^{8}$ The author has pointed out to us that a possible reason for this finding is a data problem, whereby many employees declare themselves as "self-employed" purely for tax purposes. Also, the well-being of the self-employed in Hungary appears, from the same research, to have increased over time. 


\section{THE WORLD VALUES SURVEY DATA}

All of the micro data used in the present paper comes from the integrated data set of World Values Survey and European Values Survey (WVS-EVS, or WVS for short). ${ }^{9}$ These surveys are a major multi-country effort to gain insight into people's basic values and attitudes across a broad range of issues, including politics and economics, family and religious values, gender issues and environmental awareness. The WVS has been implemented in four waves so far: (i) 1981-84, (ii) 1990-93, (iii) 1995-97, and (iv) 1999-2002. The first wave covered only 24 societies. ${ }^{10}$ The sample grew with the second wave which covered 43 societies. The third and the fourth waves covered 62 and 82 societies respectively. Thus, the latest wave of the WVS covers countries that together account for about 85 per cent of the world's population. This section and the following section focus on wave four only, which includes 19 transition countries (see Annex), while section 5 considers evidence from the earlier waves.

For our purposes, the key question from the WVS is the following, to which respondents were asked to mark their answers on a scale from 1 (most dissatisfied) to 10 (most satisfied):

"All things considered, how satisfied are you with your life as a whole these days?"

The answers vary widely both within and across countries. Figure 1 considers the crosscountry variation. It shows the mean score, by country, of the responses and compares it with a measure of objective well-being, namely GDP per capita (in current international dollars) adjusted for purchasing power parity (PPP). Since the fourth wave of the WVS-EVS was carried out over a three-year interval between 1999 and 2002, we tracked the exact timing of the survey implementation for each country, and assumed a one-year lag in GDP per capita figures in relation to the time of the survey. That is, if the survey was implemented in country X in 2001, then we compare it with the GDP per capita (PPP-adjusted) of country X in 2000.

The evidence in Figure 1 shows the expected positive relationship between GDP per capita and self-reported satisfaction, though the link between the two appears to tail off at higher levels of GDP per capita. In fact, a simple quadratic trend fits the relation quite well, with a significant correlation of 0.74 between the two series. Interestingly, most transition countries fall below this trend, with only Croatia, the Czech Republic and the Slovak Republic (three of the most advanced countries in the region) lying above the trend. ${ }^{11}$ That is, people in most transition countries tend to report lower levels of satisfaction than would be predicted by a quadratic regression of satisfaction on GDP per capita. This is the first bit of evidence from the latest wave of the WVS of the difficulties faced by individuals in the region.

\footnotetext{
${ }^{9}$ European and World Values Surveys are carried out by two separate groups of researchers, and are integrated in a data file for research purposes to ensure cross-national and across-time comparisons.

${ }^{10}$ The common units of analysis in this dataset are countries. However, societies in this context are introduced as a broader concept, since occasionally some samples, which are regionally rather than nationally representative are also surveyed. For example, Andalucia, Basque Country, Galicia, and Valencia as well as a national representative sample for Spain were surveyed in wave three. For our practical purposes, only sovereign countries were included in the econometric analyses.

${ }^{11}$ With the exception of Serbia and Montenegro, which has been treated as two separate entities by the WVS-EVS. However, comparable macroeconomic data on GDP per capita for this country were not available at this level of disaggregation.
} 


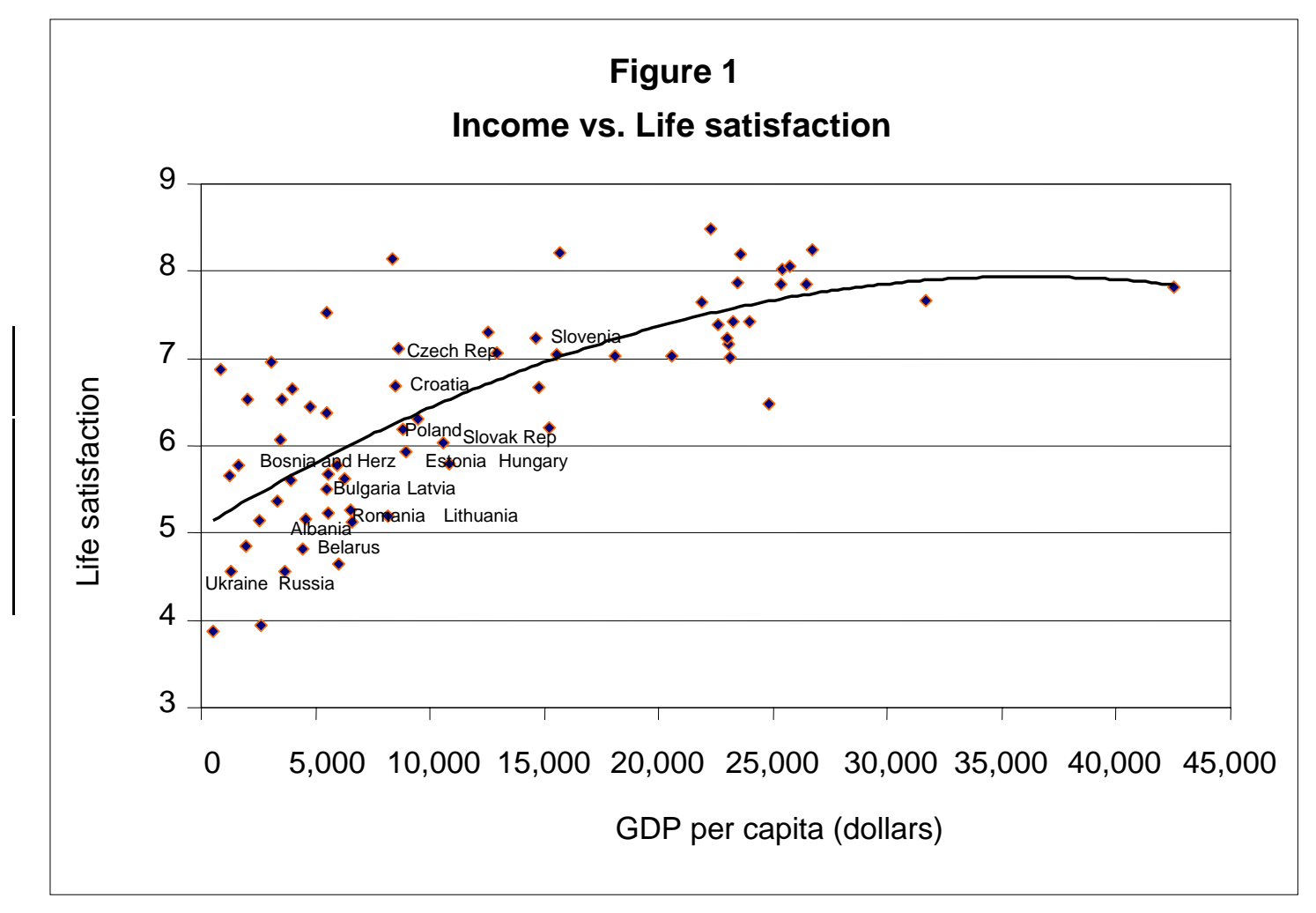

Source: WVS and World Development Indicators.

Table 1 contains a more detailed examination of where transition countries stand in relation to other countries. The table shows that four countries in the region - Moldova, Ukraine, Russia and Belarus - are in the bottom decile in terms of satisfaction scores. Two of the Baltic states - Latvia and Lithuania - are in the next-to-bottom category, along with Albania, FYR Macedonia and Romania. In general, the new EU members score much better, with Slovenia (the richest country in the region in terms of GDP per capita) in the 70-80 decile and the Czech Republic in the 60-70 category. Slovenia's score of 7.23 puts it above France (7.01) and not far off from Great Britain and Germany (7.40 and 7.42 respectively) in terms of life satisfaction.

Another way of comparing subjective measures of satisfaction with objective economic circumstances is to compare the responses to the question above with cumulative growth over the transition period (see Figure 2). People's assessments of their well-being are often influenced by their economic situation relative to what it used to be, rather than by the absolute standard of living. Indeed, this is one of the reasons why the link between GDP and happiness is much weaker once countries manage to rise to a point of reasonable prosperity. All transition countries suffered deep recessions in the early years of transition, though the duration and extent of the decline in real output varied widely from one country to the next. As Figure 2 shows, there is indeed a positive correlation between two variables: life satisfaction (on the y-axis), and an index of real GDP that takes the value of 100 for all countries in 1989 (on the $\mathrm{x}$-axis). The correlation coefficient between the two variables is 0.54 . However, there is considerable variation across countries, suggesting that many other factors are driving the responses to this question. The next section, therefore, uses econometric techniques to investigate more deeply the correlates of life satisfaction. 
Table 1: Mean of life satisfaction scores and the lowest percentiles by country

\begin{tabular}{|l|l|l|}
\hline Lowest percentiles & Country & Life satisfaction \\
\hline $0-10$ & Moldova & 4.56 \\
\cline { 2 - 3 } & Ukraine & 4.56 \\
\cline { 2 - 3 } & Russia & 4.65 \\
\cline { 2 - 3 } & Belarus & 4.81 \\
\hline $10-20$ & FYR Macedonia & 5.12 \\
\cline { 2 - 3 } & Albania & 5.17 \\
\cline { 2 - 3 } & Lithuania & 5.20 \\
\cline { 2 - 3 } & Romania & 5.23 \\
\cline { 2 - 3 } & Latvia & 5.27 \\
\hline $20-30$ & Bulgaria & 5.50 \\
\cline { 2 - 3 } & Serbia & 5.62 \\
\cline { 2 - 3 } & Montenegro & 5.64 \\
\hline $30-40$ & Bosnia and Herzegovina & 5.77 \\
\cline { 2 - 3 } & Hungary & 5.80 \\
\cline { 2 - 3 } & Estonia & 5.93 \\
\cline { 2 - 3 } & Slovak Republic & 6.03 \\
\hline $70-80$ & Poland & 6.20 \\
\hline $50-60$ & Croatia & 7.06 \\
\hline \multirow{5}{*}{$50-50$} & Czech Republic & 23 \\
\hline & Slovenia & \\
\hline
\end{tabular}

Note: The table shows the average satisfaction score by country, and the corresponding decile into which each country falls.

Source: WVS.

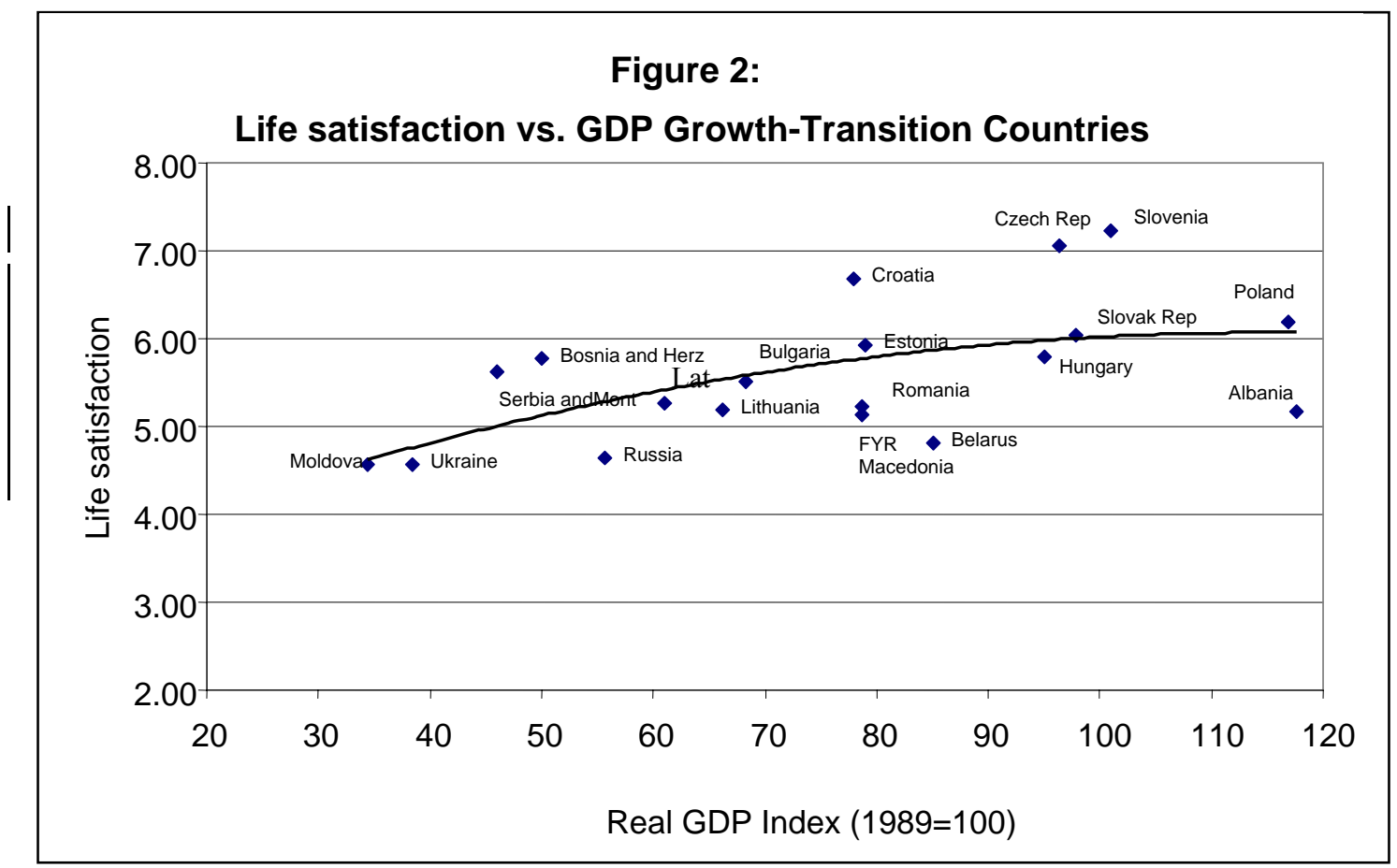

Source: WVS and EBRD (2004). 


\section{ECONOMETRIC SPECIFICATION AND RESULTS}

So far, this paper has looked at aggregate satisfaction scores across countries and their relationship with GDP. However, in order to derive a better understanding of what drives people's responses to this question, we estimate a series of microeconometric equations. Our hypothesis is that self-reported satisfaction scores are a function both of individual-specific and economy-wide variables. We, therefore, estimate the following equation:

$$
\mathrm{S}_{\mathrm{ij}}=\mathrm{f}\left(\mathrm{X}_{\mathrm{ij}}, Z_{\mathrm{j}}, \varepsilon_{\mathrm{ij}}\right) \text {, }
$$

where $S_{i j}$ is a vector of satisfaction scores (on a scale of 1 to 10 ) of individual $i$ in country $j$, $X_{i j}$ is a matrix of explanatory variables that vary across individual and country, $Z_{\mathrm{j}}$ is a matrix of macroeconomic variables that vary by country only, and $\varepsilon_{\mathrm{ij}}$ is a vector of idiosyncratic errors.

In line with much of the previous literature, we include the following microeconomic variables (all of which are taken from the WVS): gender, marital status, income group, employment status, education, and age variables. Marital status is divided into married, living together, divorced, separated, widowed, and single. Income group is divided into three dummy variables: lower income, middle income and higher income groups. The breakdown of the employment status variable is as follows: full-time (30 hours a week and more), parttime (less than 30 hours a week), self-employed, retired, housewife, student, unemployed and other. The education variable is split into: inadequately completed elementary education, completed (compulsory) primary education, incomplete secondary education (technical, vocational type), complete secondary school (technical, vocational type), incomplete secondary school (university preparatory type), complete secondary school (university preparatory type), some university education without degree, and finally university education with degree.

The macroeconomic variables in equation (1) include GDP per capita (PPP-adjusted), the unemployment rate, the inflation rate and the Gini coefficient, which captures the impact of income inequality on satisfaction. In addition, the state of reform may also be relevant for happiness in transition countries. We, therefore, include the average transition score for each country, as measured by the EBRD transition indicators. ${ }^{12}$ It is unclear a priori what the sign of this variable may be. On the one hand, progress in transition is generally associated with better economic performance, and hence a higher degree of satisfaction. On the other hand, transition is a time of upheaval and disruption, and it is possible that people in countries that lag behind in transition are (other things being equal) happier for that reason. We also experiment by dividing this variable into initial-phase reforms, which capture progress in price liberalisation, foreign exchange and trade liberalisation and small-scale privatisation, and second-phase reforms, which include large-scale privatisation, governance and enterprise restructuring, competition policy, infrastructure, banking and interest rate liberalisation, and non-bank financial institutions (see the data Annex for more details).

Up to now, we have for convenience treated our dependent variable - life satisfaction - as a cardinal measure when taking within-country averages and comparing across countries. However, there is no presumption that the difference between a score of 4 and 5, for example, is the same as that between 5 and 6 . Therefore, in line with most of the recent literature, we treat this variable in our estimation procedure as ordinal and estimate equation (1) by an ordered probit model, rather than by ordinary least squares. In the discussion that follows, a positive (and statistically significant) coefficient on an explanatory variable indicates a

\footnotetext{
${ }^{12}$ The transition indicators range from 1 (little or no progress in reform) to $4+$ (standards of an advanced industrialised economy). When calculating averages, pluses and minuses are converted to numerical equivalents by adding or subtracting 0.33 (e.g., $2+$ becomes 2.33 and 3- is 2.67). See the EBRD Transition Report, various issues, for a full description of the methodology underlying these scores.
} 
positive association with life satisfaction, in the sense that it increases the probability of being in the highest category (satisfaction $=10$ ) and decreases the probability of recording the lowest score (satisfaction $=1$ ). ${ }^{13}$

Table 2 presents the results of the ordered probit regressions for the whole sample, the transition countries sample and the non-transition countries sample, respectively in columns one to three. Our initial approach is to capture country-specific fixed effects by adding country dummies, rather than including the macroeconomic variables discussed above. We also include employment status, marital status, education, income group, age and age squared, all of which have been shown elsewhere to be important determinants of life satisfaction.

Turning first to column 1 of Table 2, which includes both transition and non-transition countries, many of the results parallel those of other cross-country studies. For example, most categories of employment status are associated with lower values of satisfaction relative to full-time employment (the omitted category in the regression). Unemployment has a particularly negative effect on satisfaction; other things being equal, being unemployed rather than full-time employed raises the probability of recording the lowest level of satisfaction by approximately three percentage points. Satisfaction tends to rise with educational status, particularly at high levels of education, and with income, while being married is associated with more satisfaction than other types of living arrangements. Finally, the data exhibit the familiar U-shape pattern with regard to age, with a minimum point at around age 46, and show males are less happy than females, a finding that appears in several other studies. ${ }^{14}$ The country dummies for transition countries (not reported in the table) are almost all negative and statistically significant relative to the reference country, Germany.

Columns 2 and 3 report the results from the same regression model for transition and nontransition countries respectively. A quick glance at the results shows a large number of similarities between the two sub-groups, but also some important differences. It is the latter that are of most interest here. Turning first to employment status highlights one of the most interesting results: self-employment in transition countries is positively (and statistically significant at 10 per cent) associated with satisfaction, whereas the sign is reversed in the nontransition case. There is evidence from previous research that, for those willing to take the risk, self-employment is a successful coping strategy in transition (see, for example, EBRD, 2000, Chapter 5, and Dutz et al., 2004). ${ }^{15}$ The results in column 2 are an interesting complement to this earlier research, and highlight the importance of further developing entrepreneurship in the transition context.

A second interesting contrast between the two samples concerns the effects of education. In both cases, education is positively correlated with higher life satisfaction, but in the transition sample this effect becomes particularly significant at higher levels of education. In the transition context, many skills acquired under the old regime became redundant once transition started, but the value of having a relatively high degree of education may have increased in the more difficult environment. This may help to explain why there is little difference in the satisfaction scores at low levels of education but a positive effect at higher levels.

A third result of interest concerns the effects of age. In both cases, we find the usual U-shape effect, but the minimum age, after which the curve slopes upwards, comes significantly later in life for those in the transition sample (52.2) as opposed to those elsewhere (44.8). ${ }^{16}$ In

\footnotetext{
${ }^{13}$ The effect on the probability of being in the intermediate categories cannot be determined solely by looking at the value of the coefficient.

${ }^{14}$ Clark (1997), for example, finds that women are significantly happier than men in the workplace.

${ }^{15}$ The self-employed may also find it easier to conceal part or all of their employment income, and this may also help to explain their relatively high scores on satisfaction.

${ }^{16}$ We have experimented with replacing the quadratic age term by dummies for age intervals (20-29, $30-39$, etc.) and the same broad conclusions hold.
} 
general, older people in transition countries have found it harder to cope with the changes brought by transition, perhaps because they have lost jobs and have little hope of finding new ones, and this may lie behind this difference.

Finally, the effect of gender is different in the two sub-samples. While males continue to be less happy than females in the non-transition case, the correlation is much weaker in the transition sample, and statistically significant only at the 10 per cent level. ${ }^{17}$ Nevertheless, we have explored whether the results in the transition region change significantly when the sample is split between males and females. By and large, the main conclusions hold, and we therefore relegate these results to the annex (See Tables A.2 and A.3).

${ }^{17}$ Part of the explanation for this result is that, in many transition countries, the relative status of women appears to have worsened during transition. 
Table 2: Satisfaction equations (WVS wave four)

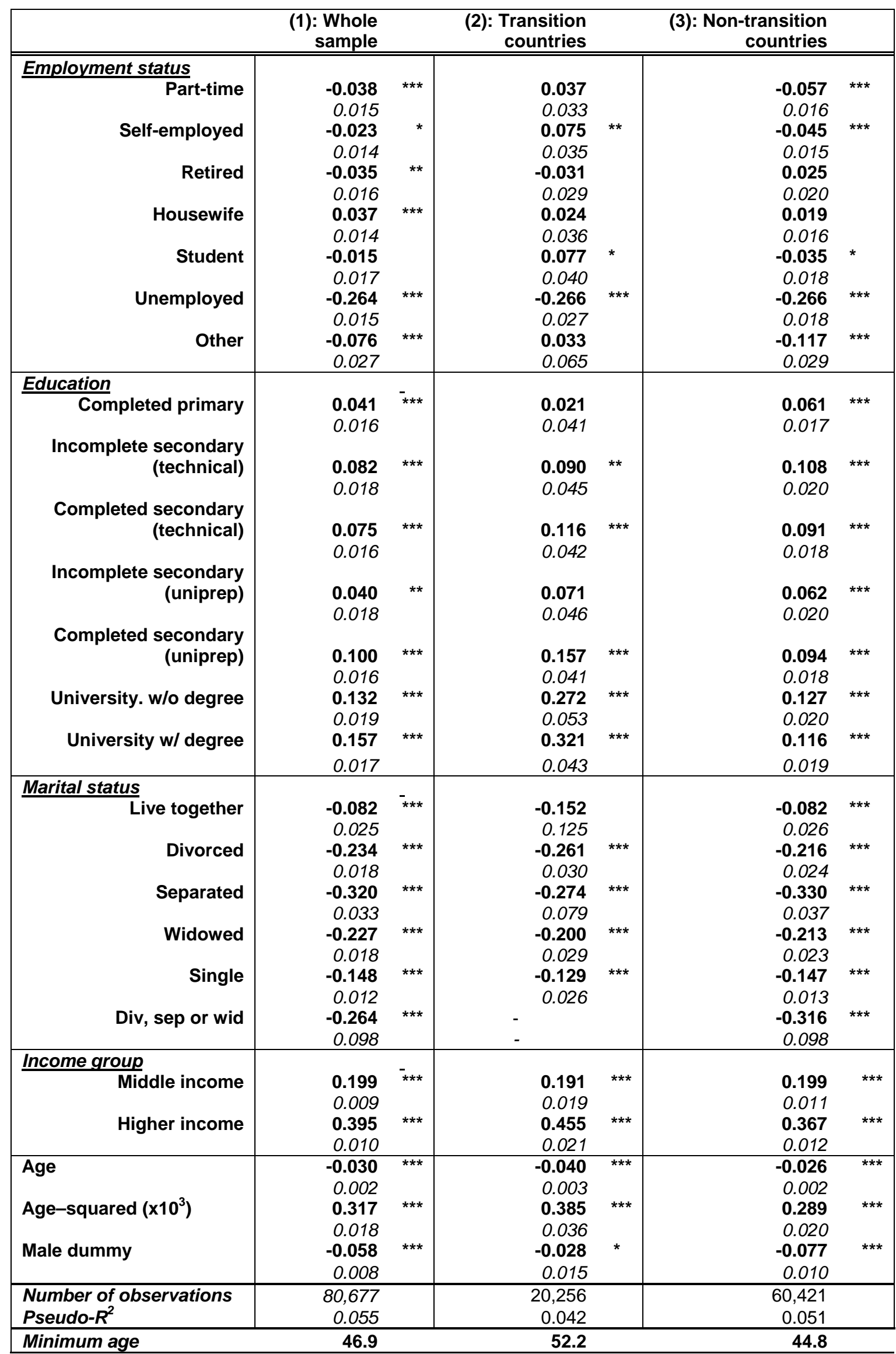

Notes: Ordered probit regressions with heteroskedasticity-robust standard errors and country fixed effects. Omitted country variable is Germany for columns 1 and 3, and Russia for column 2. For other omitted dummy variables (reference categories), see data annex.

Source: WVS. 
So far, we have restricted ourselves to analysing the individual-specific correlates of satisfaction, while country-specific differences have been absorbed in the country dummy variables. We now investigate whether important effects are coming through from macroeconomic variables, and we include these in the regression in place of the country dummies. Table 3 reports the results, again for the whole sample, the transition and the nontransition countries respectively, with four macro variables: GDP growth; the unemployment rate; end-year inflation; and the Gini coefficient (to capture income inequality). ${ }^{18}$

Turning first to the full sample, per capita GDP has the expected positive impact on the probability of happiness. Somewhat surprisingly, the Gini coefficient also has a positive sign, contradicting the a priori expectation that people dislike inequality. Neither unemployment nor inflation has a statistically significant impact on happiness. Interestingly, the effects of gender and education are now much weaker relative to the previous results.

In the transition sub-sample (column 2), several results are worth highlighting. One surprising result is the positive (and statistically significant) association between inflation and satisfaction. It is difficult to think of a good rationale for this, as the evidence from advanced countries is that inflation is generally disliked and has a negative effect on happiness. ${ }^{19}$ It is possible that inflation is correlated with wealth-distribution effects that, in net terms, have a positive effect on transition. Or low inflation may be associated with fiscal austerity and cutbacks in essential services. A second point is the strong negative effect of inequality on satisfaction (in contrast to the positive association in the non-transition case), suggesting a lingering dislike of inequality that was characteristic of socialist systems. ${ }^{20}$ Finally, the positive coefficient on self-employment found earlier remains in this case, but the statistical significance falls just short of conventional (10 per cent) levels.

\footnotetext{
${ }^{18}$ A technical problem arises when variables on the right-hand side of the equation are at a higher level of aggregation than the left-hand side variable, namely, that the standard errors are biased downwards, and hence the degree of statistical significance may be exaggerated. Intuitively, this is because these variables have a small number of independent observations relative to the size of the sample. We control for this by a "clustering" option that relaxes the assumption that the errors are independent across observations, replacing it with the assumption of independence across clusters. This leads to wider standard errors and more valid statistical inference. The method was suggested by Rogers (1993) as a generalisation of Huber (1967).

${ }^{19}$ See, for example, di Tella et al. (2003).

${ }^{20}$ Senik (2004) investigates this issue for Russia, using five years of panel data, and finds no relation between regional Gini coefficients and life satisfaction. A positive relation between the two variables, using British household panel data, is found in Clark (2004), which also provides a brief survey of other investigations into this question.
} 
Table 3: Satisfaction equations with macroeconomic variables

\begin{tabular}{|c|c|c|c|c|c|c|}
\hline & (1): Whole sample & & $\begin{array}{r}\text { (2): Transition } \\
\text { countries }\end{array}$ & & $\begin{array}{r}\text { (3): Non-transition } \\
\text { countries }\end{array}$ & \\
\hline \multirow[t]{2}{*}{ GDP per capita $\left(x 10^{3}\right)$} & 0.038 & $* * *$ & 0.089 & $* * *$ & 0.029 & *** \\
\hline & 0.005 & & 0.013 & & 0.005 & \\
\hline \multirow[t]{2}{*}{ Unemployment } & -0.003 & & 0.001 & & -0.003 & \\
\hline & 0.006 & & 0.004 & & 0.006 & \\
\hline \multirow[t]{2}{*}{ Inflation $\left(x 10^{3}\right)$} & -0.011 & & 0.052 & $* * *$ & -3.286 & *** \\
\hline & 0.027 & & 0.017 & & 1.263 & \\
\hline \multirow[t]{2}{*}{ Gini coefficient } & 0.018 & *** & -0.012 & ** & 0.023 & *** \\
\hline & 0.007 & & 0.005 & & 0.006 & \\
\hline \multicolumn{7}{|l|}{ Employment status } \\
\hline \multirow[t]{2}{*}{ Part-time } & -0.055 & * & 0.019 & & -0.076 & * \\
\hline & 0.033 & & 0.045 & & 0.032 & \\
\hline \multirow[t]{2}{*}{ Self-employed } & 0.025 & & 0.067 & & -0.054 & ** \\
\hline & 0.052 & & 0.044 & & 0.024 & \\
\hline \multirow[t]{2}{*}{ Retired } & -0.133 & $* * *$ & -0.062 & ** & -0.014 & ** \\
\hline & 0.039 & & 0.028 & & 0.035 & \\
\hline \multirow[t]{2}{*}{ Housewife } & 0.028 & & 0.082 & & -0.075 & \\
\hline & 0.063 & & 0.055 & & 0.064 & \\
\hline \multirow[t]{2}{*}{ Student } & 0.006 & & 0.126 & $* * *$ & -0.050 & \\
\hline & 0.043 & & 0.043 & & 0.037 & \\
\hline \multirow[t]{2}{*}{ Unemployed } & -0.273 & $* * *$ & -0.276 & $* * *$ & -0.287 & *** \\
\hline & 0.053 & & 0.049 & & 0.059 & \\
\hline \multirow[t]{2}{*}{ Other } & -0.049 & & -0.042 & & -0.160 & ** \\
\hline & 0.056 & & 0.091 & & 0.069 & \\
\hline \multicolumn{7}{|l|}{ Education } \\
\hline \multirow[t]{2}{*}{ Complete primary } & 0.052 & & 0.022 & & 0.111 & ** \\
\hline & 0.044 & & 0.062 & & 0.054 & \\
\hline \multirow[t]{2}{*}{$\begin{array}{r}\text { Incomplete secondary } \\
\text { (technical) }\end{array}$} & 0.055 & & 0.015 & & 0.167 & $* * *$ \\
\hline & 0.065 & & 0.099 & & 0.062 & \\
\hline \multirow[t]{2}{*}{$\begin{array}{r}\text { Complete secondary } \\
\text { (technical) }\end{array}$} & -0.016 & & 0.081 & & 0.101 & ** \\
\hline & 0.071 & & 0.081 & & 0.051 & \\
\hline \multirow[t]{2}{*}{$\begin{array}{r}\text { Incomplete secondary } \\
\text { (uniprep) }\end{array}$} & -0.005 & & -0.019 & & 0.168 & ** \\
\hline & 0.093 & & 0.101 & & 0.073 & \\
\hline \multirow[t]{2}{*}{$\begin{array}{r}\text { Complete secondary } \\
\text { (uniprep) }\end{array}$} & 0.003 & & 0.069 & & 0.102 & * \\
\hline & 0.066 & & 0.087 & & 0.057 & \\
\hline \multirow[t]{2}{*}{ University w/o degree } & 0.135 & ** & 0.238 & ** & 0.182 & * \\
\hline & 0.061 & & 0.104 & & 0.063 & \\
\hline \multirow[t]{2}{*}{ University $w /$ degree } & 0.054 & & 0.260 & *** & 0.112 & * \\
\hline & 0.062 & & 0.081 & & 0.060 & \\
\hline \multicolumn{7}{|l|}{ Marital status } \\
\hline Live together & 0.280 & * & 0.144 & $* * *$ & 0.172 & \\
\hline & 0.166 & & 0.053 & & 0.141 & \\
\hline Divorced & -0.262 & $* * *$ & -0.271 & $* * *$ & -0.119 & *** \\
\hline & 0.054 & & 0.034 & & 0.045 & \\
\hline Separated & -0.215 & $* * *$ & -0.265 & * & -0.222 & * \\
\hline & 0.061 & & 0.155 & & 0.059 & \\
\hline Widowed & -0.237 & $* * *$ & -0.222 & $* * *$ & -0.144 & *** \\
\hline & 0.044 & & 0.037 & & 0.045 & \\
\hline Single & -0.104 & $* * *$ & -0.091 & *** & -0.139 & *** \\
\hline & 0.033 & & 0.026 & & 0.037 & \\
\hline
\end{tabular}




\begin{tabular}{|c|c|c|c|c|c|c|}
\hline & (1): Whole sample & & $\begin{array}{r}\text { (2): Transition } \\
\text { countries }\end{array}$ & & $\begin{array}{r}\text { (3): Non-transition } \\
\text { countries }\end{array}$ & \\
\hline \multicolumn{7}{|l|}{ Income group } \\
\hline \multirow[t]{2}{*}{ Middle income } & 0.201 & $* * *$ & 0.194 & *** & 0.189 & $* * *$ \\
\hline & 0.028 & & 0.053 & & 0.035 & \\
\hline \multirow[t]{2}{*}{ Higher income } & 0.376 & $* * *$ & 0.423 & *** & 0.333 & *** \\
\hline & 0.057 & & 0.078 & & 0.075 & \\
\hline \multirow[t]{2}{*}{ Age } & -0.027 & $* * *$ & -0.037 & *** & -0.025 & *** \\
\hline & 0.004 & & 0.005 & & 0.005 & \\
\hline \multirow[t]{2}{*}{ Age -squared $\left(\times 10^{3}\right)$} & 0.294 & $\star * *$ & 0.346 & $* * *$ & 0.306 & *** \\
\hline & 0.045 & & 0.057 & & 0.057 & \\
\hline \multirow[t]{2}{*}{ Male dummy } & -0.041 & & -0.018 & & -0.101 & ** \\
\hline & 0.032 & & 0.030 & & 0.019 & \\
\hline $\begin{array}{l}\text { Number of } \\
\text { observations }\end{array}$ & 47,936 & & 14,394 & & 33,542 & \\
\hline Pseudo- $R^{2}$ & 0.034 & & 0.036 & & 0.03 & \\
\hline Minimum age & 45.7 & & 53.8 & & 41.1 & \\
\hline
\end{tabular}

Note: See Table 2 and the data annex for variable description and reference categories. All regressions are carried out using a "clustering" option to control for downward bias of standard errors in the presence of macroeconomic variables.

Sources: WVS and World Development Indicators.

Table 4 presents a further set of results based on the transition sample only. We now include not only the macro variables from the previous table, but also a reform indicator - the EBRD transition indicator described earlier. Column 1 suggests that this variable adds little to the explanatory power of the equation; the variable has a positive sign but is highly insignificant. However, this variable has a very close correlation (0.70) with GDP per capita, and it is likely that significant multicollinearity is present. Column 2 shows some evidence in this direction. Once we leave GDP per capita out of the regression, the EBRD Reform variable immediately assumes a positive sign and a significance level at 1 per cent. Other things being equal, the results of column 2 suggest that living in a country with an advanced level of transition $(\mathrm{EBRD}=3.52$, similar to Czech Republic) rather than a low-transition country $(\mathrm{EBRD}=1.5$, Belarus) has a substantial effect on the probability of recording the highest level of satisfaction.

To explore this issue further, we experiment in columns 3 and 4 by introducing initial- and second-phase reforms separately with GDP per capita. The results provide some support for the positive role of initial-phase reforms, as this variable is positive and statistically significant (at 10 per cent), in the presence of GDP per capita in the regression. Second-phase reforms have a negative sign but the coefficient is not statistically significant. Finally, in column 5, we introduce all of the aforementioned variables simultaneously, and the same conclusions hold. 
Table 4: Satisfaction equations with macroeconomic and reform variables

\begin{tabular}{|c|c|c|c|c|c|c|c|c|c|c|}
\hline & (1) & & (2) & & (3) & & (4) & & (5) & \\
\hline \multirow[t]{2}{*}{ GDP per capita $\left(\times 10^{3}\right)$} & 0.085 & $\star \star \star *$ & - & & 0.081 & *** & 0.090 & $* * *$ & 0.094 & * \\
\hline & 0.015 & & - & & 0.012 & & 0.016 & & 0.011 & \\
\hline \multirow[t]{2}{*}{ Unemployment } & 0.000 & & -0.012 & & -0.004 & & 0.001 & & -0.013 & \\
\hline & 0.005 & & 0.009 & & 0.006 & & 0.004 & & 0.010 & \\
\hline \multirow[t]{2}{*}{ Inflation $\left(\times 10^{3}\right)$} & 0.053 & & 0.036 & & 0.057 & *** & 0.052 & $* * *$ & 0.063 & * \\
\hline & 0.016 & & 0.023 & & 0.016 & & 0.017 & & 0.016 & \\
\hline \multirow[t]{2}{*}{ Gini coefficient } & -0.012 & ** & -0.013 & ** & -0.010 & ** & -0.012 & ** & -0.006 & * \\
\hline & 0.005 & & 0.006 & & 0.005 & & 0.005 & & 0.005 & \\
\hline \multirow[t]{2}{*}{ EBRD Reform } & 0.038 & & 0.357 & *** & - & & - & & - & \\
\hline & 0.083 & & 0.094 & & - & & - & & - & \\
\hline \multirow[t]{2}{*}{ EBRD1-Initial Phase Reform } & - & & - & & 0.081 & * & - & & 0.227 & * \\
\hline & - & & - & & 0.048 & & - & & 0.129 & \\
\hline \multirow[t]{2}{*}{ EBRD2-Second Phase Reform } & - & & - & & - & & -0.004 & & -0.239 & \\
\hline & - & & - & & & & 0.112 & & 0.191 & \\
\hline \multicolumn{11}{|l|}{ Employment status } \\
\hline \multirow[t]{2}{*}{ Part-time } & 0.019 & & -0.038 & & 0.020 & & 0.019 & & 0.023 & \\
\hline & 0.045 & & 0.052 & & 0.045 & & 0.045 & & 0.046 & \\
\hline \multirow[t]{2}{*}{ Self-employed } & 0.068 & & 0.022 & & 0.066 & & 0.067 & & 0.059 & \\
\hline & 0.043 & & 0.057 & & 0.043 & & 0.043 & & 0.040 & \\
\hline \multirow[t]{2}{*}{ Retired } & -0.064 & ** & -0.084 & *** & -0.067 & ** & -0.062 & ** & -0.067 & ** \\
\hline & 0.029 & & 0.026 & & 0.027 & & 0.030 & & 0.029 & \\
\hline \multirow[t]{2}{*}{ Housewife } & 0.078 & & 0.002 & & 0.068 & & 0.082 & & 0.054 & \\
\hline & 0.058 & & 0.075 & & 0.056 & & 0.057 & & 0.051 & \\
\hline \multirow[t]{2}{*}{ Student } & 0.123 & $* * *$ & 0.073 & ** & 0.116 & $* * *$ & 0.126 & $* * *$ & 0.108 & ** \\
\hline & 0.043 & & 0.043 & & 0.042 & & 0.043 & & 0.042 & \\
\hline \multirow[t]{2}{*}{ Unemployed } & -0.279 & $\star \star \star *$ & -0.331 & $* * *$ & -0.286 & $* * *$ & -0.276 & 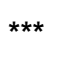 & -0.288 & * \\
\hline & 0.050 & & 0.043 & & 0.049 & & 0.050 & & 0.049 & \\
\hline \multirow[t]{2}{*}{ Other } & -0.047 & & -0.074 & & -0.050 & & -0.042 & & -0.032 & \\
\hline & 0.090 & & 0.092 & & 0.091 & & 0.090 & & 0.085 & \\
\hline \multicolumn{11}{|l|}{ Education } \\
\hline \multirow[t]{2}{*}{ Completed primary } & 0.025 & & 0.096 & * & 0.036 & & 0.022 & & 0.052 & \\
\hline & 0.058 & & 0.051 & & 0.059 & & 0.060 & & 0.065 & \\
\hline \multirow[t]{2}{*}{$\begin{array}{r}\text { Incomplete secondary } \\
\text { (technical) }\end{array}$} & 0.012 & & 0.020 & & 0.022 & & 0.016 & & 0.072 & \\
\hline & 0.095 & & 0.090 & & 0.095 & & 0.094 & & 0.091 & \\
\hline \multirow[t]{2}{*}{$\begin{array}{r}\text { Completed secondary } \\
\text { (technical) }\end{array}$} & 0.085 & & 0.132 & * & 0.093 & & 0.080 & & 0.093 & \\
\hline & 0.076 & & 0.080 & & 0.077 & & 0.076 & & 0.070 & \\
\hline \multirow[t]{2}{*}{ Incomplete secondary (uniprep) } & -0.008 & & 0.085 & & 0.012 & & -0.020 & & 0.018 & \\
\hline & 0.092 & & 0.119 & & 0.096 & & 0.091 & & 0.090 & \\
\hline \multirow[t]{2}{*}{ Completed secondary (uniprep) } & 0.072 & & 0.102 & & 0.083 & & 0.069 & & 0.103 & \\
\hline & 0.083 & & 0.075 & & 0.082 & & 0.086 & & 0.086 & \\
\hline University. wlo degree & 0.239 & ** & 0.252 & ** & 0.243 & ** & 0.238 & ** & 0.250 & ** \\
\hline & 0.104 & & 0.102 & & 0.103 & & 0.104 & & 0.102 & \\
\hline University w/ degree & 0.264 & $* * *$ & 0.285 & $* * *$ & 0.275 & *** & 0.260 & *** & 0.288 & $*$ \\
\hline & 0.077 & & 0.075 & & 0.076 & & 0.078 & & 0.074 & \\
\hline
\end{tabular}




\begin{tabular}{|c|c|c|c|c|c|c|c|c|c|c|}
\hline & \multicolumn{2}{|l|}{ (1) } & \multicolumn{2}{|l|}{ (2) } & \multicolumn{2}{|l|}{ (3) } & \multicolumn{2}{|l|}{$(4)$} & \multicolumn{2}{|l|}{ (5) } \\
\hline Marital status & & & & & & & & & & \\
\hline \multirow[t]{2}{*}{ Live together } & 0.131 & ** & -0.161 & & 0.106 & & 0.145 & $* * *$ & 0.099 & \\
\hline & 0.062 & & 0.135 & & 0.067 & & 0.056 & & 0.068 & \\
\hline \multirow[t]{2}{*}{ Divorced } & -0.271 & $* * *$ & -0.248 & $* * *$ & -0.268 & $* * *$ & -0.271 & $* * *$ & -0.257 & * \\
\hline & 0.034 & & 0.046 & & 0.034 & & 0.034 & & 0.036 & \\
\hline \multirow[t]{2}{*}{ Separated } & -0.267 & * & -0.260 & * & -0.266 & * & -0.265 & * & -0.258 & * \\
\hline & 0.155 & & 0.152 & & 0.154 & & 0.154 & & 0.153 & \\
\hline \multirow[t]{2}{*}{ Widowed } & -0.222 & $* * *$ & -0.220 & $* * *$ & -0.221 & $\star * *$ & -0.222 & *** & -0.218 & $\begin{array}{l}\text { ** } \\
\text { * }\end{array}$ \\
\hline & 0.037 & & 0.042 & & 0.038 & & 0.037 & & 0.037 & \\
\hline \multirow[t]{2}{*}{ Single } & -0.091 & $* * *$ & -0.059 & ** & -0.092 & $* * *$ & -0.091 & $* * *$ & -0.096 & * \\
\hline & 0.025 & & 0.028 & & 0.026 & & 0.026 & & 0.028 & \\
\hline \multicolumn{11}{|l|}{ Income group } \\
\hline \multirow[t]{2}{*}{ Middle income } & 0.193 & $* * *$ & 0.191 & $* * *$ & 0.192 & $* * *$ & 0.194 & ** & 0.197 & * \\
\hline & 0.053 & & 0.054 & & 0.052 & & 0.052 & & 0.051 & \\
\hline \multirow[t]{2}{*}{ Higher income } & 0.420 & $* * *$ & 0.403 & $* * *$ & 0.415 & $\star * *$ & 0.423 & $* * *$ & 0.418 & * \\
\hline & 0.079 & & 0.083 & & 0.078 & & 0.079 & & 0.080 & \\
\hline \multirow[t]{2}{*}{ Age } & -0.037 & $* * *$ & -0.036 & $* * *$ & -0.038 & $* * *$ & -0.037 & $* \star *$ & -0.039 & $\begin{array}{l}\text { ** } \\
\text { * }\end{array}$ \\
\hline & 0.005 & & 0.006 & & 0.005 & & 0.005 & & 0.005 & \\
\hline \multirow[t]{2}{*}{ Age -squared $\left(\times 10^{3}\right)$} & 0.347 & $* * *$ & 0.336 & $* * *$ & 0.352 & $* * *$ & 0.346 & *** & 0.361 & * \\
\hline & 0.058 & & 0.064 & & 0.058 & & 0.057 & & 0.058 & \\
\hline \multirow[t]{2}{*}{ Male dummy } & -0.019 & & -0.020 & & -0.020 & & -0.02 & & -0.02 & \\
\hline & 0.030 & & 0.033 & & 0.030 & & 0.03 & & 0.03 & \\
\hline Number of observations & 14,394 & & 14,394 & & 14,394 & & 14,394 & & 14,394 & \\
\hline Pseudo- $R^{2}$ & 0.036 & & 0.030 & & 0.036 & & 0.036 & & 0.037 & \\
\hline Minimum age & 53.8 & & 53.9 & & 53.8 & & 53.8 & & 53.6 & \\
\hline
\end{tabular}

Note: See Table 3.

Sources: WVS, World Development Indicators, and EBRD (2004). 


\section{HAPPINESS THROUGH TIME}

As noted earlier, the WVS was first carried out in the period 1981-84, and the analysis in this paper so far has focused on the fourth wave of the survey (1999-2002). It would be of great interest to be able to compare our results for this latest wave with those based on earlier years, and indeed to carry out one large regression with both country and time dummies. This section explores this approach. Unfortunately, the sample of countries available is significantly smaller than when we focus on the fourth wave only. Furthermore, the first wave contains very few observations on the current transition countries. Hence, we focus on waves two through four in the remainder of this paper.

Table 5 below shows the average transition score by country for each wave for which data are available. By focusing on those countries where three waves are available, there is clear evidence of a V-shape pattern of satisfaction through time (see also Figure 3, where we plot the pattern for countries with three data points available). That is, most countries saw a decline in their average score between waves two and three, but a recovery between waves three and four. In two cases (Bulgaria and Slovenia), the average score in wave four is above that recorded in wave two.

Table 5: Life satisfaction through time

\begin{tabular}{|c|c|c|c|}
\hline Countries & $\begin{array}{r}\text { Wave } 2 \\
(1990-93)\end{array}$ & $\begin{array}{r}\text { Wave } 3 \\
(1995-97)\end{array}$ & $\begin{array}{r}\text { Wave } 4 \\
(1999- \\
2002)\end{array}$ \\
\hline Bulgaria & 5.03 & 4.66 & 5.50 \\
\hline Belarus & 5.52 & 4.35 & 4.81 \\
\hline Estonia & 6.00 & 5.00 & 5.93 \\
\hline Latvia & 5.70 & 4.90 & 5.27 \\
\hline Lithuania & 6.01 & 4.99 & 5.20 \\
\hline Poland & 6.64 & 6.42 & 6.20 \\
\hline Russia & 5.37 & 4.45 & 4.65 \\
\hline Slovenia & 6.29 & 6.46 & 7.23 \\
\hline Bosnia and Herzegovina & 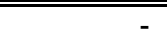 & 5.46 & 5.77 \\
\hline Croatia & - & 6.18 & 6.68 \\
\hline Czech Republic & 6.37 & - & 7.06 \\
\hline Hungary & 6.03 & - & 5.80 \\
\hline Romania & 5.88 & - & 5.23 \\
\hline Slovak Republic & 6.15 & - & 6.03 \\
\hline Ukraine & - & 3.95 & 4.56 \\
\hline Serbia & - & 5.56 & 5.62 \\
\hline Montenegro & - & 6.21 & 5.64 \\
\hline Albania & - & 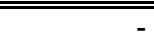 & 5.17 \\
\hline Azerbaijan & - & 5.39 & - \\
\hline Armenia & - & 4.32 & - \\
\hline Georgia & - & 4.65 & - \\
\hline FYR Macedonia & - & - & 4.56 \\
\hline Moldova & - & 3.73 & - \\
\hline
\end{tabular}

Note: The table shows the average satisfaction score by country for each available wave of the WVS. Source: WVS (waves 2-4). 


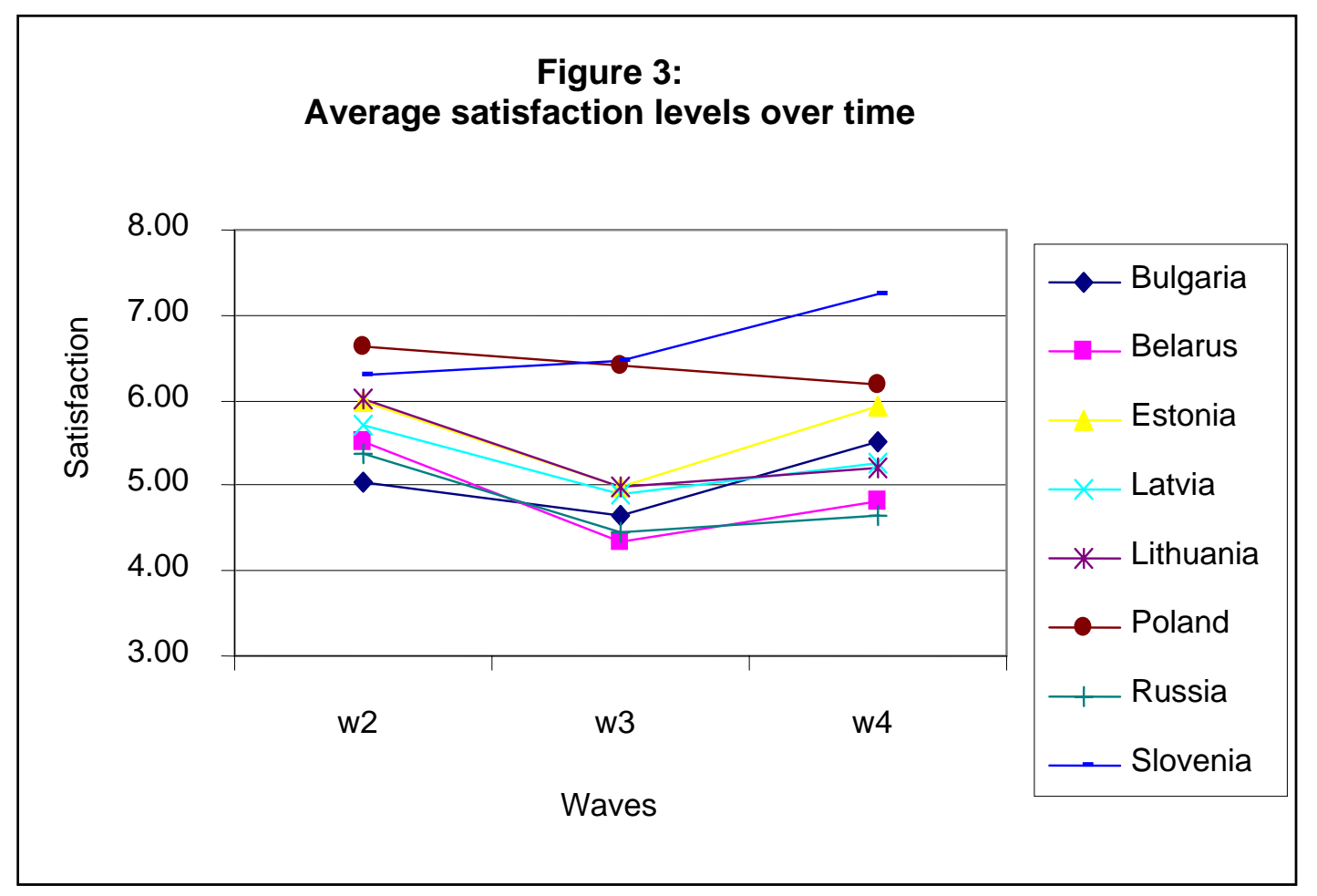

Source: WVS (waves 2-4).

Table 6 reports the results of a multi-wave regression, using countries for which data from waves two, three and four are available. Time dummies are included for waves three and four (with wave two being the reference category). Interestingly, these dummies are negative and significant in both the transition and non-transition sample, as well as in the overall sample. However, the wave three dummy is more negative than wave four in the transition case, in contrast to the non-transition sample where it is less negative. This suggests that there may be some convergence in scores, with satisfaction levels in transition countries moving closer to those in non-transition countries. Other results are largely in line with those discussed earlier (from wave four only). In particular, the positive and statistically significant coefficient on self-employment in transition holds for this multi-wave analysis, whereas it is negative and significant in the non-transition case. 
Table 6: Satisfaction equations with time dummies

\begin{tabular}{|c|c|c|c|c|c|c|}
\hline & (1) & & (2) & & (3) & \\
\hline Wave 3 dummy & $\begin{array}{r}-0.127 \\
0.011\end{array}$ & *** & $\begin{array}{r}-0.308 \\
0.023\end{array}$ & $\overline{c * \star \star}$ & $\begin{array}{r}-0.062 \\
0.013\end{array}$ & 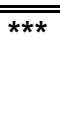 \\
\hline Wave 4 dummy & $\begin{array}{r}-0.096 \\
0.012\end{array}$ & $* * *$ & $\begin{array}{r}-0.167 \\
0.024\end{array}$ & *** & $\begin{array}{r}-0.087 \\
0.013\end{array}$ & *** \\
\hline Employment status & & & & & & \\
\hline Part-time & $\begin{array}{r}-0.024 \\
0.011\end{array}$ & ** & $\begin{array}{l}\mathbf{0 . 0 4 9} \\
0.020\end{array}$ & ** & $\begin{array}{r}-0.058 \\
0.013\end{array}$ & *** \\
\hline Self-employed & $\begin{array}{r}-0.007 \\
0.011\end{array}$ & & $\begin{array}{l}\mathbf{0 . 0 4 9} \\
0.023\end{array}$ & ** & $\begin{array}{r}-0.031 \\
0.012\end{array}$ & *** \\
\hline Retired & $\begin{array}{r}-0.051 \\
0.012\end{array}$ & $* * *$ & $\begin{array}{r}-0.039 \\
0.021\end{array}$ & * & $\begin{array}{r}-0.001 \\
0.016\end{array}$ & \\
\hline Housewife & $\begin{array}{l}0.051 \\
0.011\end{array}$ & $* * *$ & $\begin{array}{l}\mathbf{0 . 0 2 1} \\
0.024\end{array}$ & & $\begin{array}{l}\mathbf{0 . 0 3 1} \\
0.012\end{array}$ & ** \\
\hline Student & $\begin{array}{r}-0.002 \\
0.013\end{array}$ & & $\begin{array}{l}0.095 \\
0.028\end{array}$ & *** & $\begin{array}{r}-0.030 \\
0.014\end{array}$ & ** \\
\hline Unemployed & $\begin{array}{r}-0.247 \\
0.011\end{array}$ & $* * *$ & $\begin{array}{r}-0.222 \\
0.019\end{array}$ & *** & $\begin{array}{r}-0.263 \\
0.014\end{array}$ & *** \\
\hline Other & $\begin{array}{r}-0.081 \\
0.020\end{array}$ & $* * *$ & $\begin{array}{l}\mathbf{0 . 0 1 7} \\
0.038\end{array}$ & & $\begin{array}{r}-0.134 \\
0.024\end{array}$ & *** \\
\hline Education & & & & & & \\
\hline Completed primary & $\begin{array}{l}\mathbf{0 . 0 6 9} \\
0.014\end{array}$ & $* * *$ & $\begin{array}{l}\mathbf{0 . 0 4 6} \\
0.034\end{array}$ & & $\begin{array}{l}\mathbf{0 . 0 8 6} \\
0.015\end{array}$ & *** \\
\hline $\begin{array}{r}\text { Incomplete secondary } \\
\text { (technical) }\end{array}$ & $\begin{array}{l}0.151 \\
0.014\end{array}$ & $* * *$ & $\begin{array}{l}0.111 \\
0.035\end{array}$ & $* * *$ & $\begin{array}{l}0.185 \\
0.016\end{array}$ & *** \\
\hline $\begin{array}{r}\text { Completed secondary } \\
\text { (technical) }\end{array}$ & $\begin{array}{l}0.149 \\
0.014\end{array}$ & *** & $\begin{array}{l}0.110 \\
0.036\end{array}$ & $\star \star \star *$ & $\begin{array}{l}0.177 \\
0.015\end{array}$ & *** \\
\hline $\begin{array}{r}\text { Incomplete secondary } \\
\text { (uniprep) }\end{array}$ & $\begin{array}{l}0.126 \\
0.014\end{array}$ & $\star \star \star ~$ & $\begin{array}{l}0.186 \\
0.036\end{array}$ & $\star \star \star *$ & $\begin{array}{l}0.121 \\
0.016\end{array}$ & $\star \star * \star$ \\
\hline $\begin{array}{r}\text { Completed secondary } \\
\text { (uniprep) }\end{array}$ & $\begin{array}{l}0.148 \\
0.014\end{array}$ & $* * *$ & $\begin{array}{l}0.123 \\
0.035\end{array}$ & $* * *$ & $\begin{array}{l}0.163 \\
0.016\end{array}$ & *** \\
\hline University w/o degree & $\begin{array}{l}0.175 \\
0.015\end{array}$ & $* * *$ & $\begin{array}{l}0.178 \\
0.037\end{array}$ & $\star \star \star *$ & $\begin{array}{l}0.201 \\
0.016\end{array}$ & *** \\
\hline University $\mathrm{w} /$ degree & $\begin{array}{l}0.227 \\
0.014\end{array}$ & $* * *$ & $\begin{array}{l}0.279 \\
0.035\end{array}$ & *** & $\begin{array}{l}0.213 \\
0.015\end{array}$ & *** \\
\hline
\end{tabular}




\begin{tabular}{|c|c|c|c|c|c|c|}
\hline & (1) & & (2) & & (3) & \\
\hline \multicolumn{7}{|l|}{ Marital status } \\
\hline \multirow[t]{2}{*}{ Live together } & -0.137 & $* * *$ & -0.175 & $* * *$ & -0.126 & *** \\
\hline & 0.015 & & 0.039 & & 0.017 & \\
\hline \multirow[t]{2}{*}{ Divorced } & -0.233 & $* * *$ & -0.250 & *** & -0.227 & *** \\
\hline & 0.014 & & 0.022 & & 0.018 & \\
\hline \multirow[t]{2}{*}{ Separated } & -0.333 & $* *$ & -0.309 & *** & -0.343 & \\
\hline & 0.024 & & 0.050 & & 0.028 & \\
\hline \multirow[t]{2}{*}{ Widowed } & -0.217 & $* * *$ & -0.196 & 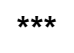 & -0.203 & $\star * *$ \\
\hline & 0.013 & & 0.021 & & 0.018 & \\
\hline \multirow[t]{2}{*}{ Single } & -0.164 & $* * *$ & -0.114 & ** & -0.171 & *** \\
\hline & 0.009 & & 0.018 & & 0.010 & \\
\hline \multirow[t]{2}{*}{ Div, sep or wid } & -0.248 & ** & - & & -0.307 & *** \\
\hline & 0.097 & & - & & 0.096 & \\
\hline \multicolumn{7}{|l|}{ Income group } \\
\hline \multirow[t]{2}{*}{ Middle income } & 0.203 & $* * *$ & 0.241 & *** & 0.186 & *** \\
\hline & 0.007 & & 0.013 & & 0.008 & \\
\hline \multirow[t]{2}{*}{ Higher income } & 0.376 & $* * *$ & 0.513 & *** & 0.321 & *** \\
\hline & 0.008 & & 0.016 & & 0.009 & \\
\hline \multirow[t]{2}{*}{ Age } & -0.031 & $* \star *$ & -0.039 & *** & -0.027 & *** \\
\hline & 0.001 & & 0.002 & & 0.001 & \\
\hline \multirow[t]{2}{*}{ Agesquared } & 0.000 & $* * *$ & 0.000 & $* * *$ & 0.000 & $* * *$ \\
\hline & 0.000 & & 0.000 & & 0.000 & \\
\hline \multirow[t]{2}{*}{ Male dummy } & -0.039 & $* * *$ & -0.003 & & -0.061 & $* * *$ \\
\hline & 0.006 & & 0.011 & & 0.008 & \\
\hline Number of observations & 140,245 & & 41,802 & & 98,443 & \\
\hline Pseudo- $R^{2}$ & 0.055 & & 0.044 & & 0.039 & \\
\hline Minimum age & 46.9 & & 52.2 & & 44.3 & \\
\hline
\end{tabular}

Note: See Table 3.

Source: WVS (waves 2-4). 


\section{CONCLUSION}

This paper is one of the first to analyse life satisfaction in a range of transition countries. The paper documents the deep dissatisfaction felt by many people in the region, even after a decade of transition. However, the overall picture has positive aspects too. In countries for which several time periods of evidence are available, life satisfaction appears to be rising on average, after dipping to its lowest point in the mid-1990s. More importantly, the level of happiness across countries is closely correlated with the progress made in transition, as well as with overall GDP per capita. Given that the region appears to be on a sustained growth path, and good progress continues to be made in transition (both trends highlighted in EBRD, 2004), life satisfaction is likely to rise further in transition countries. Thus, the answer to the question posed by this paper's title - does transition make you happy? - is a mixed one. Clearly, for many people in this region, transition has been a difficult and painful experience. But it is also clear that people are generally happier in countries that have made more progress in transition than in those where transition has lagged.

The analysis in this paper does not lend itself to strong policy conclusions. Nevertheless, several points are suggested by the analysis above. Two aspects are worth emphasising. First, it is important to have a renewed effort to improve the well-being of vulnerable groups. These include older people, whose skills are often irrelevant for the new challenges, and those with limited education. Second, entrepreneurship can be a rewarding strategy in transition. The paper has provided some tentative evidence that such people are, on average, happier even than those with full-time jobs. This highlights the importance of creating an enabling business environment where new enterprises can be set up easily and the provision of commerciallyoriented micro-finance is encouraged. 


\section{REFERENCES}

D. Blanchflower and A.J. Oswald (2004), "Well-being over time in Britain and the USA", Journal of Public Economics, Vol. 88, pp. 1,359-1,386.

A.E. Clark (1997), “Job satisfaction and gender: why are women so happy at work?”, Labour Economics, Vol. 4, pp. 341-372.

A.E. Clark (2004), "Inequality-aversion and income mobility: a direct test", mimeo, CNRS and DELTA-Fédération Jourdan.

A.E. Clark, A.J. Oswald and P.B. Warr (1996), "Is job satisfaction U-shaped in age?", Journal of Occupational and Organizational Psychology, Vol. 69, pp. 57-81.

E. Diener and M.E.P. Seligman (2004), "Beyond money: toward an economy of well being", Psychological Science in the Public Interest, Vol.5, No. 1, pp. 1-31.

R. Di Tella, R. MacCulloch and A.J. Oswald (2003), "Preferences over inflation and unemployment: evidence from surveys of happiness", American Economic Review, Vol. 91, pp. 335-341.

M. Dutz, C. Kauffmann, S. Najarian, P. Sanfey and R. Yemtsov (2004), "Labor market states, mobility and entrepreneurship in transition economies", Brazilian Journal of Business Economics, Vol. 4, No. 2, pp. 37-49

EBRD (2000), Transition Report 2000: Employment, skills and transition, London, EBRD.

EBRD (2004), Transition Report 2004: Infrastructure, London, EBRD.

E. Falcetti, T. Lysenko and P. Sanfey (2005), "Reforms and growth in transition: reexamining the evidence", EBRD Working Paper No. 90.

B.S Frey and A. Stutzer (2002a), Happiness and economics: how the economy and institutions affect human well-being, Princeton University Press.

B.S. Frey and A. Stutzer (2002b), "What can economists learn from happiness research?", Journal of Economic Literature, Vol. 40, pp. 402-435.

C. Graham (2004), "Assessing the impact of globalization on poverty and inequality: a new lens on an old puzzle", paper prepared for the Brookings Trade Forum.

C. Graham, A. Eggers and S. Sukhtankar (2004), "Does happiness pay? An exploration based on panel data from Russia", Journal of Economic Behavior and Organization, Vol. 55, pp. 319-342.

C. Gruen and S. Klasen (2005), "Has transition improved well-being? An analysis based on income, inequality-adjusted income, non-income, and subjective well-being measures", mimeo, University of Goettingen.

B. Hayo and W. Seifert (2002), "Subjective well-being in Eastern Europe", University of Essen Economics Department Discussion Paper No. 120.

J.F Helliwell (2002) "How's life? Combining individual and national variables to explain subjective well-being”, NBER Working Paper 9,065.

P.J. Huber (1967), "The behavior of maximum likelihood estimates under non-standard conditions", in Proceedings of the Fifth Berkeley Symposium on Mathematical Statistics and Probability, Berkeley, CA, University of Berkeley Press, 1: pp. 221-233.

R. Inglehart, M. Basanez, J. Diez-Medrano, L. Halman and R. Luijk (eds.) (2004), Human beliefs and values: A cross-cultural sourcebook based on the 1999-2002 values surveys, Siglo XXI Editores.

R. Inglehart, et al. (2003) World Values Surveys and European Values Surveys, 1981-1984, 1990-1993, and 1995-1997 [Computer file]. ICPSR 2790. Ann Arbor, MI: Institute for Social 
Research [producer], 1999. Ann Arbor, MI: Inter-university Consortium for Political and Social Research [distributor].

P.R.G Layard (2005), Happiness: lessons from a new science, Allen Lane.

O. Lelkes (2002), "Tasting freedom: happiness, religion and economic transition", London School of Economics, CASE Paper No. 59.

C. Namazie and P. Sanfey (2001), "Happiness and transition: the case of Kyrgyzstan", Review of Development Economics, Vol. 5, No. 3, pp. 392-405.

A.J. Oswald (1997), "Happiness and economic performance", Economic Journal, Vol. 107, pp. $1,815-1,831$.

W.H. Rogers (1993), "sg:17: Regression standard errors in clustered samples", Stata Technical Bulletin, Vol. 13, pp. 19-23.

C. Senik (2004), "When information dominates comparison: a panel data analysis using Russian subjective data", Journal of Public Economics, Vol. 88, pp. 2099-2123. 


\section{ANNEX}

\section{A.1: Data Appendix}

\begin{tabular}{|c|c|c|c|}
\hline Variable name & Source & Definition & $\begin{array}{l}\text { Descriptive } \\
\text { statistics - Wave } \\
4\end{array}$ \\
\hline Life satisfaction & $\begin{array}{l}\text { World Values Survey-European } \\
\text { Values Survey, Waves } 2 \text { to } 4 .\end{array}$ & $\begin{array}{l}\text { "All things considered, how satisfied are you with your life as a } \\
\text { whole these days?" } 1 \text { (most dissatisfied) - } 10 \text { (satisfied) }\end{array}$ & $\begin{array}{l}\text { Mean= } 6.43 \\
\text { Standard } \\
\text { deviation=2.56 }\end{array}$ \\
\hline $\begin{array}{l}\text { EBRD transition } \\
\text { indicators }\end{array}$ & $\begin{array}{l}\text { EBRD rating from } 1 \text { (no reform) to } \\
4+\text { (standards typical of market } \\
\text { economies). For the purposes of } \\
\text { this paper all "-" and "+" scores } \\
\text { were converted into decimal points } \\
\text { by subtracting or adding } 0.33 \\
\text { points. }\end{array}$ & $\begin{array}{l}\text { EBRD Reform is the simple average of reform ratings for all the } \\
\text { nine transition indicators: price liberalisation, trade liberalisation, } \\
\text { small-scale privatisation, large-scale privatisation, corporate } \\
\text { governance and enterprise reform, competition policy, banking } \\
\text { reform and interest rate liberalisation, securities markets and } \\
\text { non-bank financial institutions, and infrastructure. EBRD1 (Initial } \\
\text { Phase Reforms) is an average of price liberalisation, foreign } \\
\text { exchange and trade liberalisation and small-scale privatisation. } \\
\text { EBRD2 is an average of the remaining six indicators. For } \\
\text { details, see Transition Report } 2004 \text {. }\end{array}$ & $\begin{array}{l}\text { Mean=2.92 } \\
\text { Standard } \\
\text { deviation=.52 }\end{array}$ \\
\hline GDP per capita & $\begin{array}{l}\text { World Development Indicators } \\
2004\end{array}$ & GDP per capita, PPP (current international US\$) & $\begin{array}{l}\text { Mean=11,744 } \\
\text { Standard } \\
\text { deviation=9,337 }\end{array}$ \\
\hline Unemployment & $\begin{array}{l}\text { World Development Indicators } \\
2004\end{array}$ & Unemployment, total (\% of total labour force) & $\begin{array}{l}\text { Mean=-10.60 } \\
\text { Standard } \\
\text { deviation=7.35 }\end{array}$ \\
\hline Gini coefficient & $\begin{array}{l}\text { World Development Indicators } \\
2004\end{array}$ & $\begin{array}{l}\text { GINI index, measures inequality on a } 0 \text { (perfect equality) to } 1 \\
\text { (perfect inequality) basis. }\end{array}$ & $\begin{array}{l}\text { Mean=36.97 } \\
\text { Standard } \\
\text { deviation=7.72 }\end{array}$ \\
\hline Inflation & $\begin{array}{l}\text { World Development Indicators } \\
2004\end{array}$ & Inflation, consumer prices (annual \%) & $\begin{array}{l}\text { Mean=45.96 } \\
\text { Standard } \\
\text { deviation=317.87 }\end{array}$ \\
\hline
\end{tabular}




\begin{tabular}{|c|c|c|c|}
\hline Employment status & $\begin{array}{l}\text { World Values Survey-European } \\
\text { Values Survey, Waves } 2 \text { to } 4 .\end{array}$ & $\begin{array}{l}\text { "Are you employed now?" Reference category: full time } \\
\text { employment } 30 \text { hours p.w. or more. }\end{array}$ & $\begin{array}{l}\text { Mean=-2.03 } \\
\text { Standard } \\
\text { Deviation }=8.30\end{array}$ \\
\hline Marital status & $\begin{array}{l}\text { World Values Survey-European } \\
\text { Values Survey, Waves } 2 \text { to } 4 .\end{array}$ & "Are you ......?" Reference category: Married & $\begin{array}{l}\text { Mean }=2.73 \\
\text { Standard } \\
\text { deviation=2.22 }\end{array}$ \\
\hline Income scale & $\begin{array}{l}\text { World Values Survey-European } \\
\text { Values Survey, Waves } 2 \text { to } 4 .\end{array}$ & $\begin{array}{l}\text { Self-assessment between lower, middle and higher income } \\
\text { groups. } \\
\text { Reference category: Lower Income }\end{array}$ & $\begin{array}{l}\text { Mean=1.97 } \\
\text { Standard } \\
\text { deviation=.81 }\end{array}$ \\
\hline Education & $\begin{array}{l}\text { World Values Survey-European } \\
\text { Values Survey, Waves } 2 \text { to } 4 .\end{array}$ & $\begin{array}{l}\text { Highest educational level attained. Reference category: } \\
\text { Inadequately completed elementary education }\end{array}$ & $\begin{array}{l}\text { Mean }=4.33 \\
\text { Standard } \\
\text { deviation=2.27 }\end{array}$ \\
\hline Age & $\begin{array}{l}\text { World Values Survey-European } \\
\text { Values Survey, Waves } 2 \text { to } 4 .\end{array}$ & Demographic variable for age & $\begin{array}{l}\text { Mean=41.35 } \\
\text { Standard } \\
\text { deviation=16.41 }\end{array}$ \\
\hline Male & $\begin{array}{l}\text { World Values Survey-European } \\
\text { Values Survey, Waves } 2 \text { to } 4 .\end{array}$ & Dummy variable for males & $\begin{array}{l}\text { Mean }=.48 \\
\text { Standard } \\
\text { deviation }=.50\end{array}$ \\
\hline Transition & $\begin{array}{l}\text { World Values Survey-European } \\
\text { Values Survey, Waves } 2 \text { to } 4 .\end{array}$ & Dummy variable for transition countries & $\begin{array}{l}\text { Mean=.24 } \\
\text { Standard } \\
\text { deviation }=.42\end{array}$ \\
\hline
\end{tabular}


A.2: Regressions appendix: regressions in their entirety with female and male sub-samples

Table A.2: (All sample of WVS Wave 4) with country fixed effects

Omitted variable: Germany for 1-3 \& 7-9, Russia for 4-6

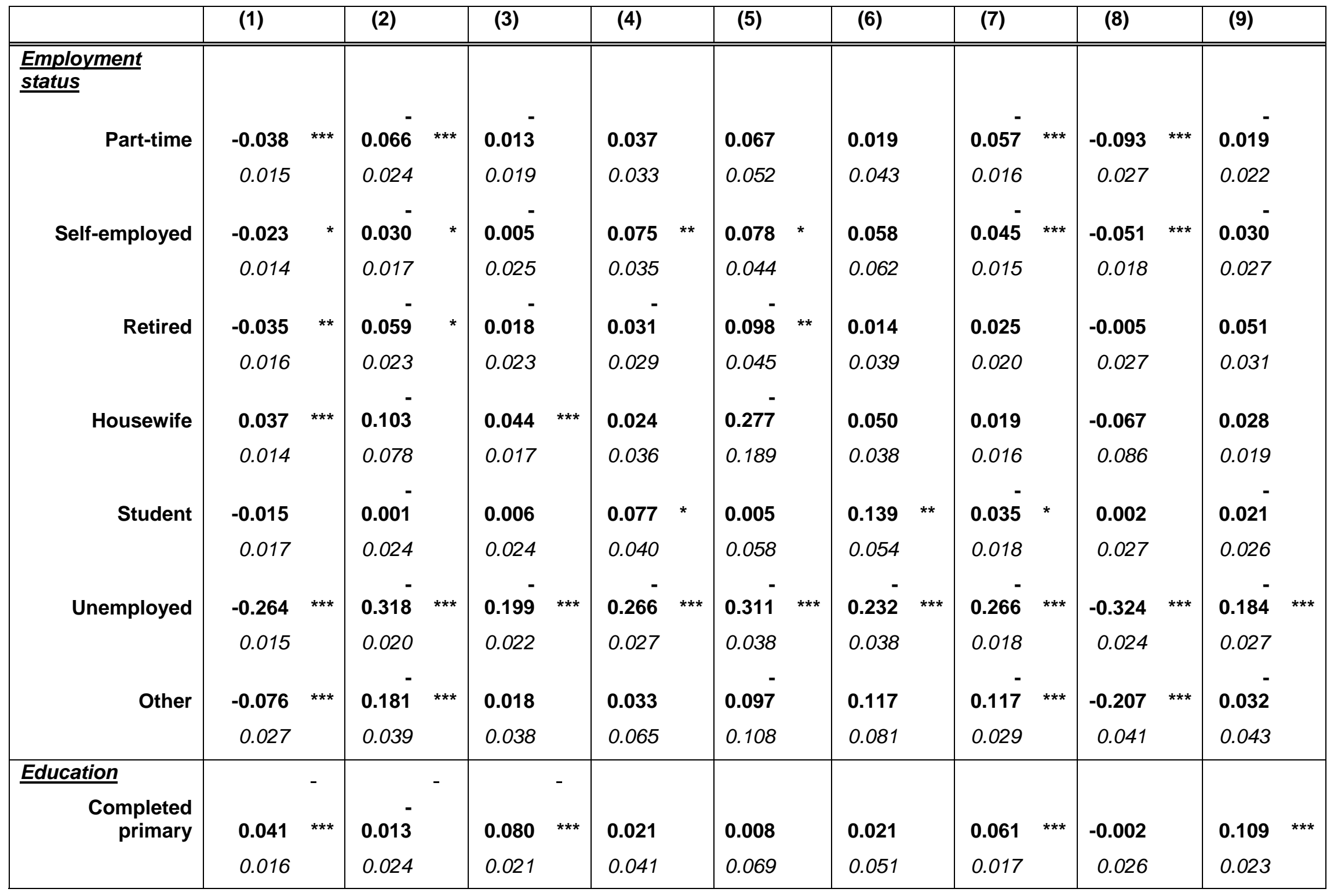




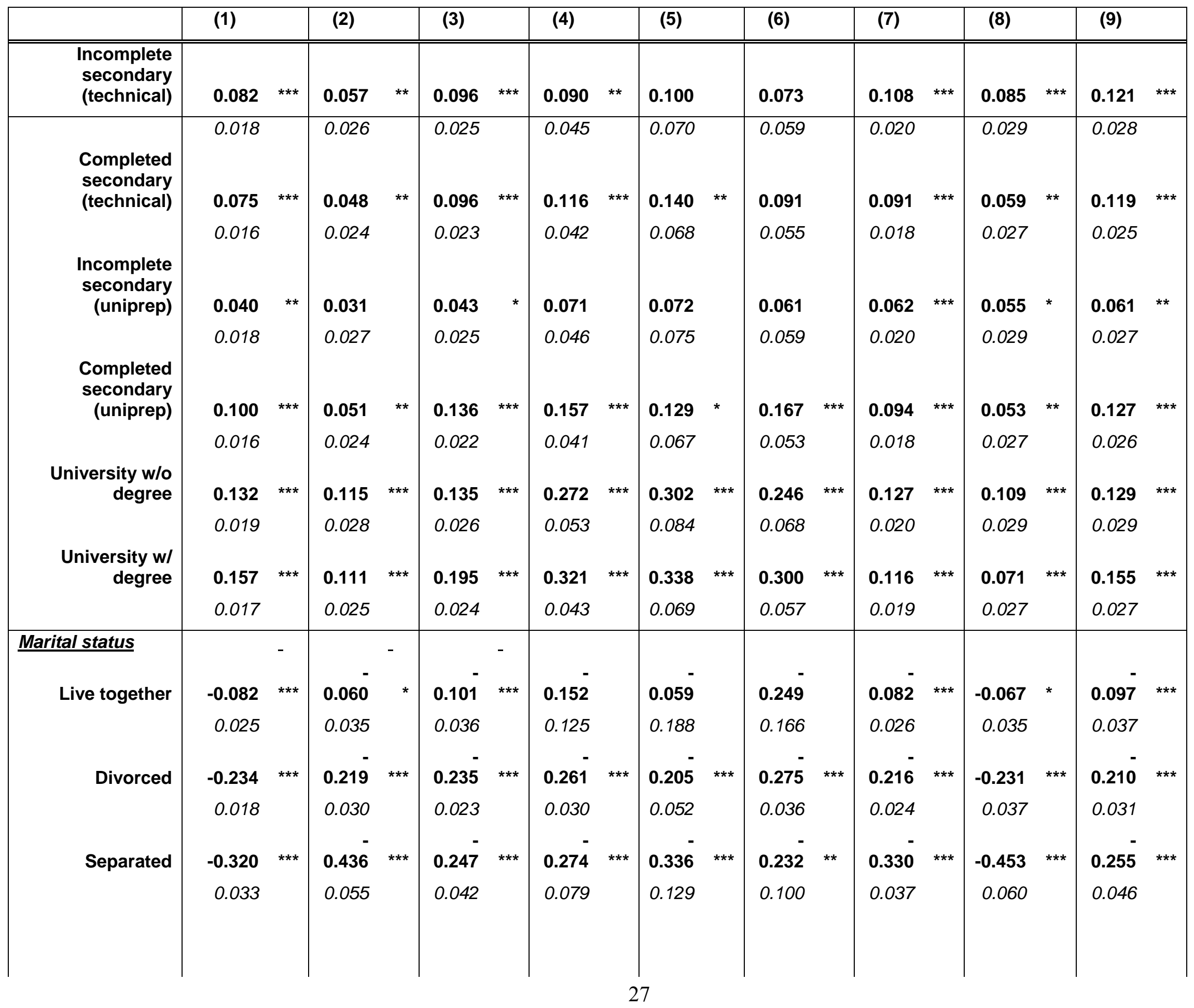




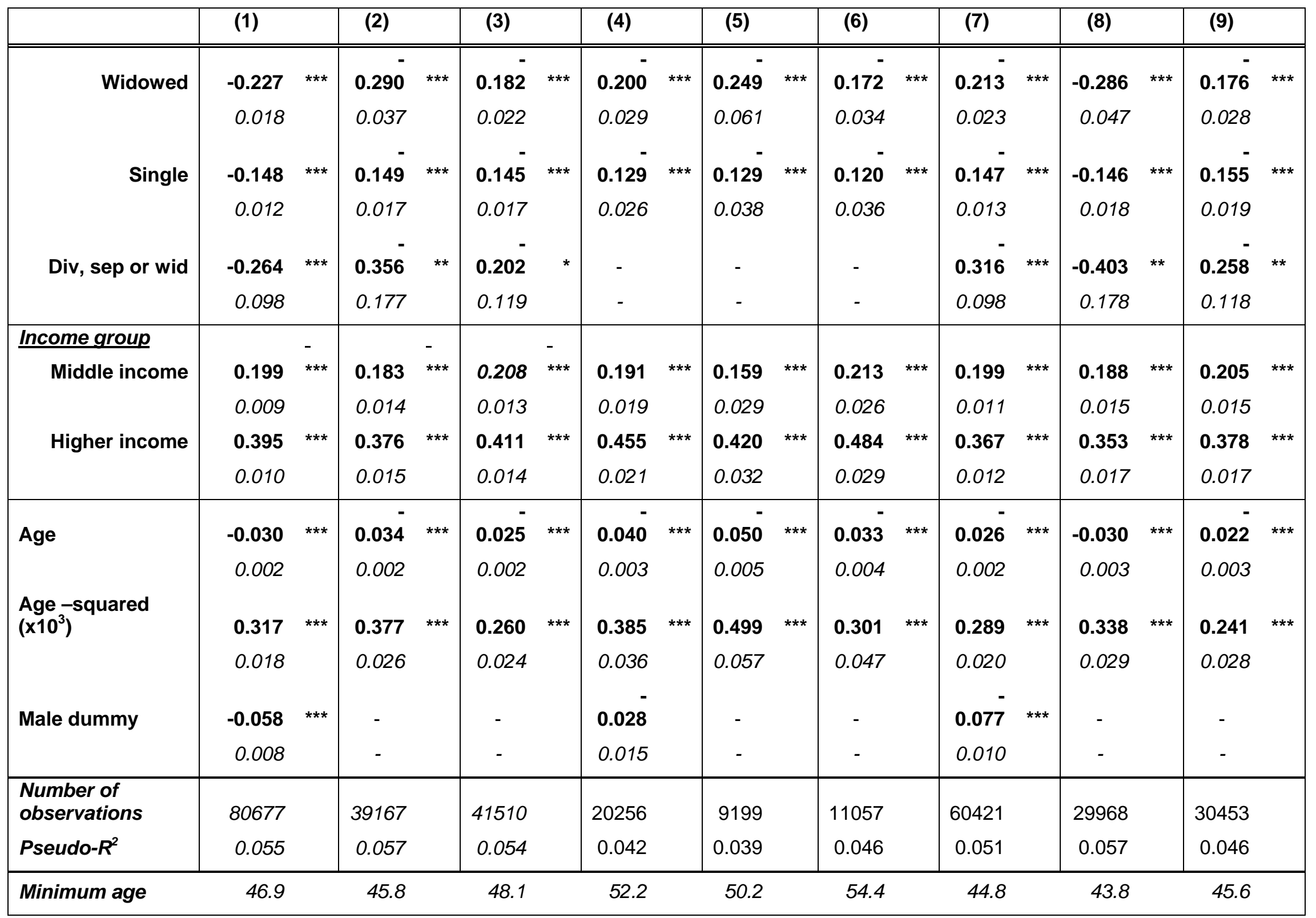

Notes: Ordered probit regressions with heteroskedasticity-robust standard errors. Columns are ordered as follows: (1): the whole sample, (2) the whole sample restricted to males only, (3) the whole sample restricted to females, (4) the transition countries sample, (5) the transition countries sample restricted to males, (6) the transition countries sample restricted to females, (7) the non-transition countries sample, (8) the non-transition countries sample restricted to males, (9) the non-transition sample restricted to females. 
Table A.3: (All sample of WVS Wave 4) without country fixed effects

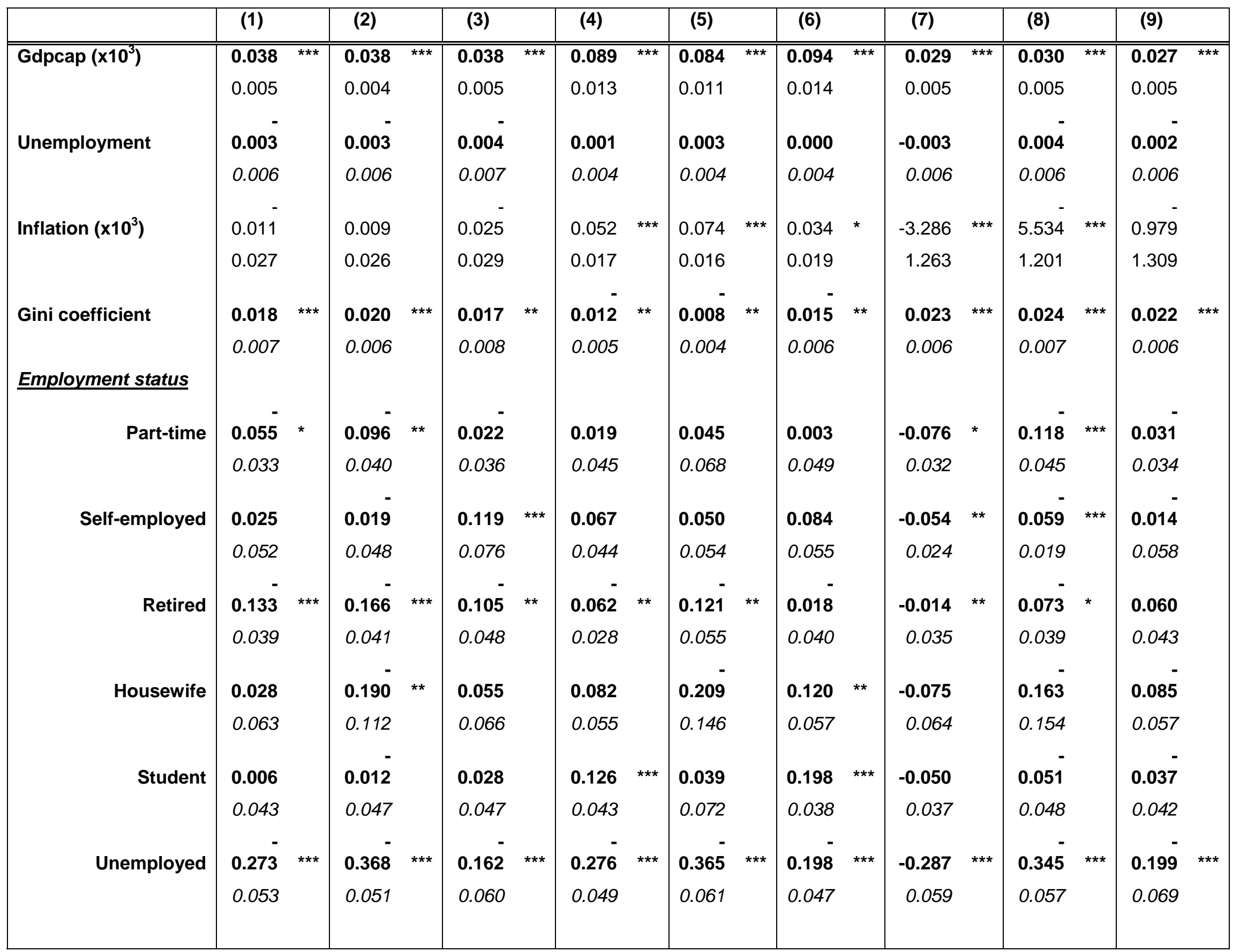




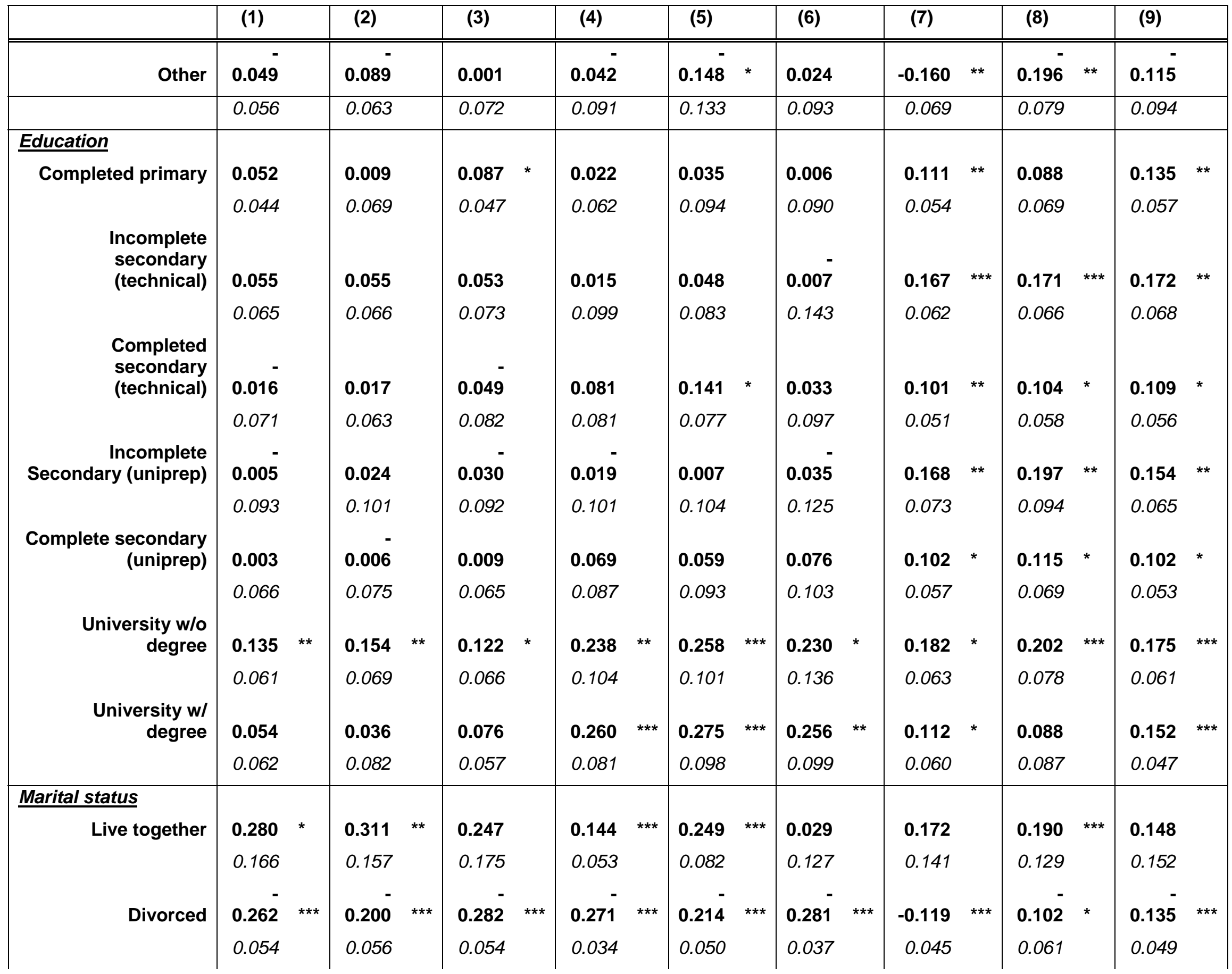




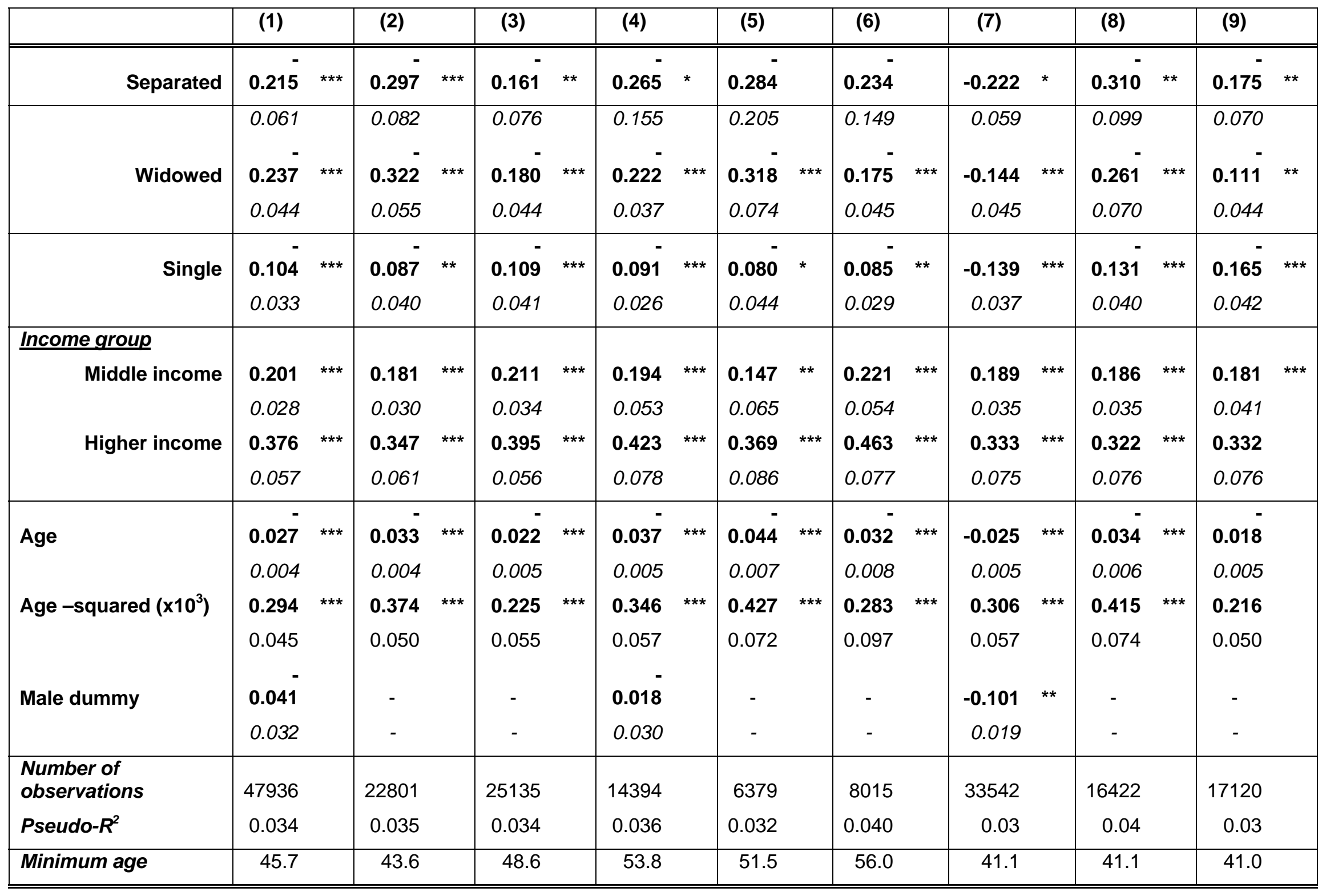

Notes: Ordered probit regressions with robust standard errors, corrected for clustering on country. Columns are ordered as follows: (1): the whole sample, (2) the whole sample restricted to males only, (3) the whole sample restricted to females, (4) the transition countries sample, (5) the transition countries sample restricted to males, (6) the transition countries sample restricted to females, (7) the non-transition countries sample, (8) the non-transition countries sample restricted to males, (9) the non-transition sample restricted to females. 